\title{
A POLÍTICA DO CÁRCERE DURO Bangu 1
}

Cesar Caldeira

Resumo: A trajetória da criação e da aplicação do Regime Disciplinar Especial de Segurança no Presídio Bangu 1, no Rio de Janeiro, é analisada criticamente. Em resistência a essa política, ocorreram depredações e paralisações na cidade em 2002 e 2003. Essa desordem sociopolítica é também diagnosticada no estudo. Palavras-chave: política penitenciária; crime organizado; segurança pública.

Abstract: The history of the creation and application of the Special Security Disciplinary Regime in the Bangu 1 Prison, in Rio de Janeiro is analyzed with a critical eye. Vandalism and shutdowns were ordered in that city in 2002 and 2003 in protest of this policy. The resulting socio-political disorder is also examined in this study. Key words: penitentiary policy; organized crime; public safety.

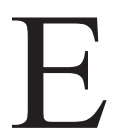

ste estudo apresenta a história do presente ${ }^{1}$ de um mecanismo de controle prisional: a "política de cárcere duro"2 no Estado do Rio de Janeiro. Trata-se do Regime Disciplinar Especial de Segurança RDES aplicado aos líderes e integrantes das facções criminosas, bem como aos presos que venham a transgredir, de forma grave, as regras previstas na Lei de Execução Penal e no Regulamento Penitenciário. O problema que se discute aqui é o da construção e da aplicação dessa política de controle e castigo. Em resistência a essa política, ocorreram depredações e paralisações na cidade do Rio de Janeiro em 2002 e 2003. Pretende-se também fazer um diagnóstico dessa desordem sociopolítica.

A hipótese central de trabalho é a seguinte. A política penitenciária é condicionada por dois fatores interligados, que se condicionam reciprocamente: os controles formais, autorizados pela legislação, que devem orientar a atuação das agências do sistema penal, e controles sociais informais, que estão enraizados nas atividades e interações cotidianas da sociedade civil. As instituições formais do sistema penal, em particular a política penitenciária, reagem aos problemas e se adaptam às novas circunstâncias. De fato, os controles sociais formais suplementam os con- troles sociais informais cotidianos, apesar de, às vezes, interferirem diretamente nesses mecanismos, produzindo efeitos perversos.

Investigar um novo padrão de política penitenciária requer, ao mesmo tempo, que se detalhem mudanças no comportamento e na cultura dos criminosos encarcerados e da sociedade assim como das instituições de controle penal que buscam produzir a ordem pública.

Focalizar uma política específica de controle sobre lideranças da criminalidade organizada introduz, no entanto, sérios problemas. Primeiro, reduz a visibilidade de uma das principais causas da desordem carcerária: as violências que os "donos da cadeia" e os guardas penitenciários praticam contra os presos pobres. ${ }^{3}$ Segundo, ao se selecionarem para análise episódios de crise prisional, como tentativas de fuga seguidas de rebeliões com reféns, silencia-se sobre as condições desumanas do encarceramento, que degradam cotidianamente a todos.

Insiste-se, mesmo assim, neste estudo, em isolar uma peculiar política de controle. Pergunta-se, então: Qual é o novo problema na criminalidade e na (des)ordem social para o qual a política do "cárcere duro" é uma resposta? Quais foram os fatores sociais que propiciaram a emer- 
gência desse novo padrão de política penitenciária em São Paulo, no governo Alckmin, e no Rio de Janeiro, no governo de Benedita da Silva?

\section{NÃO EXISTE PRESÍDIO DE SEGURANÇA MÁXIMA, EXISTE PRISÃO DE VIGILÂNCIA MÁXIMA}

Sem vigilância estatal não se garante qualquer ordem pública nas prisões. Bangu 1, um presídio de "segurança máxima", construído para 48 presos, oferece dois exemplos de como o público teve notícia de que os presos se comunicavam com o exterior. E mais, como as autoridades na época responderam aos fatos.

Em setembro de 1995, o traficante Sérgio de Mendonça, o "Ratazana", foi apontado pelo prefeito Cesar Maia (PFL) como mentor de um plano para matá-lo. Inconformado com a acusação, o bandido enviou um fax de Bangu 1 para a Prefeitura negando a existência do plano para assassinar Cesar Maia ou seu filho Rodrigo. O prefeito protestou publicamente contra o uso do fax. O governador Marcello Alencar (PSDB) reagiu indignado: "É um absurdo que alguém pense que houve erro de vigilância em Bangu 1". ${ }^{4}$

No episódio, noticiado em 10 de fevereiro de 1998, são adicionados requisitos supostamente legais para evitar investigações.

"O secretário de Segurança, Nilton Cerqueira, reconheceu ontem serem verdadeiras as acusações feitas na TV pelo traficante José Carlos dos Reis Encina, o Escadinha, de que no presídio de segurança máxima Bangu 1, onde o bandido cumpre pena, entram irregularmente armas e telefones celulares para os presos, com a conivência de policiais. No entanto, o secretário estadual de Justiça, Jorge Loretti, diz que somente serão investigadas as denúncias por escrito." ${ }^{5}$

No dia 22 de janeiro de 2001, foi encontrado um túnel de 86 metros de extensão e 1,70 metro de altura, a seis metros de profundidade, iluminado e com sistemas de drenagem e refrigeração. Todo em concreto, o caminho, que começava em uma casa na Favela de Catiri, a 150 metros do presídio, chegaria, em linha reta, até Bangu 3 e depois ligaria o presídio até Bangu 1, que fica ao lado. ${ }^{6}$

Celulares em presídios não são mais notícia depois da megarrebelião do Primeiro Comando da Capital - PPC, em São Paulo, em fevereiro de 2001. ${ }^{7}$ Mesmo assim, algumas declarações e propostas polêmicas ainda chamam a atenção. Anthony Garotinho, atual secretário de Segu- rança Pública do Estado do Rio de Janeiro, chegou a defender a liberação do uso de celulares em presídios, para fazer escutas autorizadas pela Justiça e obter informações sobre as quadrilhas. A governadora Rosinha Garotinho, ao assumir o cargo, chegou a cogitar a retirada do bloqueador de Bangu 1, mas voltou atrás. ${ }^{8}$

\section{PRIMEIRO GOVERNO GAROTINHO} (1998 - ABRIL 2002)

Em setembro de 2000, a diretora de Bangu 1, Sidneya dos Santos Jesus, foi assassinada a tiros, quando voltava do trabalho, em frente à sua casa, na Ilha do Governador. Esse é um momento particularmente importante na história da crise do sistema penitenciário do Rio. Conhecida por ser rígida com os internos, Sidneya constatou que alguns deles recebiam até cinco visitas do advogado no mesmo dia. Elaborou, então, uma lista com 130 nomes de advogados suspeitos de serem mensageiros de traficantes "pomboscorreios", e encaminhou o relatório à CPI do Narcotráfico. ${ }^{9}$

A morte de Sidneya foi um marco no relacionamento entre agentes do Departamento de Sistema Penitenciário - Desipe e presos, e o secretário de Justiça, João Luiz Duboc Pinaud. Os agentes penitenciários entraram em greve, que durou 14 horas, em protesto pela morte de Sidneya. Exigiam também a contratação imediata de pelo menos mil novos agentes, melhores condições de trabalho e um plano de cargos e salários. ${ }^{10}$ Os grevistas recusavam-se a negociar com o secretário Pinaud, que identificavam como defensor dos direitos dos presos, e reivindicavam sua exoneração. ${ }^{11}$ Os agentes proibiram visitas aos presos. ${ }^{12}$

A Polícia Militar foi chamada para restabelecer a ordem e liberar as visitas aos presos. Os grevistas desafiaram essas ordens. Os familiares dos detentos protestaram, e o governador Garotinho precisou enviar o secretário de Segurança Pública ao complexo de Bangu. As lideranças sindicais foram repudiadas por tentarem parar o movimento, que só terminou no fim do dia. Os agentes penitenciários encerraram a greve antes que os policiais militares assumissem o controle das penitenciárias. Depois desse episódio, a Polícia Militar passou a ser o instrumento privilegiado para a intervenção do governo em assuntos prisionais..$^{13}$ Em junho de 2001, discutia-se a possibilidade de o Desipe sair da esfera da Secretaria de Justiça e Direitos Humanos para subordinar-se à Secretaria de Segurança Pública - medida que estaria sendo estudada pelo governador Anthony Garotinho. ${ }^{14}$ 


\section{Comando Vermelho e Primeiro Comando da Capital: afinidades perigosas}

A megarrebelião do PCC em São Paulo, em fevereiro de 2001, trouxe apenas um reforço de mais 300 policiais militares ${ }^{15}$ para fazer a segurança em volta dos presídios do Estado do Rio de Janeiro, principalmente do complexo de Bangu e de Frei Caneca. As autoridades não previam que rebeliões geradas por insatisfação das lideranças dos comandos do Rio fossem prováveis. O deputado estadual Hélio Luz (PT-RJ), chefe da Polícia Civil no governo Alencar explicava: “(...)nos últimos 15 anos, quem manda no sistema penitenciário daqui são os presos. Em São Paulo, a rebelião só ocorreu porque o Estado separou as lideranças, mostrando que elas não têm o controle. No Rio não há rebelião porque estão juntas, como querem". ${ }^{16}$

A imprensa, no entanto, divulgava, em março de 2001, que o PCC paulista tinha coligação com o Comando Vermelho carioca, e que "há planos de começar a fazer 'atos terroristas ' para obrigar o governo a melhorar a situação dos detentos nos presídios do eixo Rio-São Paulo". ${ }^{17} \mathrm{~A}$ propósito, o item 16 do Estatuto do PCC afirma: "Em coligação com o Comando Vermelho - CV, iremos revolucionar o país dentro das prisões, e o nosso braço armado será o terror dos poderosos, opressores e tiranos que usam o anexo de Taubaté e o Bangu 1, do Rio de Janeiro, como instrumentos de vingança da sociedade e fabricação de monstros". ${ }^{18}$

O resgate de 14 traficantes ligados ao Comando Vermelho na sede da Polinter, ${ }^{19}$ localizada na Praça Mauá (zona portuária do Rio), em 29 de outubro de 2001, foi uma operação audaciosa, que demonstrou capacidade organizacional e operacional. ${ }^{20}$ Em dezembro de 2001, descobriu-se um grupo que supostamente pretendia seqüestrar o secretário de Direitos Humanos e Sistema Penitenciário, João Luiz Duboc Pinaud, para exigir a libertação de cúmplices do PCC. De fato, havia três líderes do PCC no Rio, a pedido do Ministério da Justiça, que solicitara sigilo a respeito do assunto. ${ }^{21}$ Por fim, afirmava-se que líderes do PCC presos em Bangu 1 tinham dado ordem para realizar atentados a bomba, rebeliões, executar rivais e matar o líder Mizael Aparecido da Silva ${ }^{22}$ em São Paulo. ${ }^{23}$

\section{Regime Disciplinar Diferenciado de São Paulo: a resposta estatal ao desafio do PCC}

O secretário de Administração Penitenciária, Nagashi Furukawa, respondeu à megarrebelião com um conjunto de resoluções administrativas. Na resolução SAP n ${ }^{\circ} 11$ de $13 / 03 / 2001$, estipula as medidas administrativas a serem tomadas perante a ocorrência de rebeliões ou qualquer tipo de manifestação violenta. Considera-se rebelião o ato de indisciplina iniciado pelos presos, com danos materiais ao prédio e/ou manutenção de reféns $\left(\operatorname{art} .1^{\circ}, \S 1^{\circ}\right)$.

A resolução SAP n ${ }^{\circ} 26$ de 4 de maio de 2001, que servirá de inspiração para projetos de leis federais e resoluções no Rio, regulamenta a inclusão, permanência e exclusão dos presos no RDD.

Em novembro de 2002, o delegado Godofredo Bittencourt, diretor do Departamento de Investigações sobre o Crime Organizado - Deic, já atribuía ao RDD a desarticulação do PCC. Sem acesso a celulares, os líderes passaram a se comunicar por intermédio de suas mulheres e, devido a uma rede de intrigas e inveja, a estratégia teria quebrado a hegemonia entre os chefões e supostamente provocado a derrocada do grupo. ${ }^{24}$

\section{GOVERNO BENEDITA (ABRIL DE 2002 - DEZEMBRO DE 2002)}

$$
\text { Bons tempos em que só se tinha }
$$
medo de bandido solto ${ }^{25}$

A crise tornou-se mais aguda no sistema penitenciário do Estado do Rio de Janeiro durante o governo da sucessora de Anthony Garotinho, Benedita da Silva (PT). ${ }^{26}$ Além das rebeliões carcerárias, a opinião pública percebeu que se tornara vulnerável nas ruas às ordens que vinham de chefes do tráfico encarcerados.

No dia 26 de abril de 2002, o traficante Fernandinho Beira-Mar chegou ao Rio de Janeiro, transferido por decisão da Justiça. O secretário de Segurança Pública do Estado, Roberto Aguiar, disse que a transferência, que considerava "um perigo para a população carioca", ${ }^{27}$ fora fruto de um acordo com integrantes do governo Garotinho. O ministro da Justiça, Miguel Reale Júnior, afirmou que Bangu 1 era mais seguro que a carceragem da Polícia Federal, em Brasília. No Rio, o secretário de Justiça e Sistema Penitenciário, Paulo Saboya, anunciou o aumento do número de agentes e medidas para evitar o contato de Beira-Mar com outros presos. ${ }^{28}$ Desde então, ficou claro para a opinião pública o receio das autoridades de que um traficante importante do Comando Vermelho não possa ser efetivamente isolado. Esta falta de condições de segurança nos presídios fluminenses para acolher o 
traficante comprometeu irremediavelmente a credibilidade no sistema penitenciário.

De fevereiro a dezembro de 2002, a imprensa registrou tentativas de fuga, fugas efetivadas e rebeliões no complexo de Bangu, todas em presídios e casas de custódia dominados pelo Comando Vermelho. Aconteceram ao todo onze "incidentes prisionais". ${ }^{29}$

No dia 14 de maio, o prédio da Secretaria de Direitos Humanos, onde ficava também a sede do Desipe, foi alvejado por dezenas de tiros de fuzil. Foram colados na frente do prédio dois cartazes onde se lia: "Chega de opressão. Daqui pra frente qualquer ação arbitrária com nossos irmãos na cadeia será dada resposta à altura". O texto era assinado CV-RL-PJ. ${ }^{30}$ Dois dias depois, o ministro da Justiça, Miguel Reale Júnior, manifestou sua intenção de criar uma força-tarefa para combater o crime organizado no Rio, ao que a governadora Benedita responde: "ainda não há necessidade disso". ${ }^{31}$

O assassinato brutal do jornalista Tim Lopes, ${ }^{32}$ da Rede Globo, repercutiu na opinião pública e nas perspectivas das autoridades governamentais. Na cerimônia do segundo aniversário do Plano Nacional de Segurança Pública, o presidente Fernando Henrique elevou o "crime organizado" à condição de inimigo número 1 do país, e anunciou que o combate à violência era a prioridade máxima na agenda nacional. ${ }^{33}$

No dia 18 de junho, quatro promotores do Ministério Público do Rio - MPE, com apoio de 100 policiais do Bope, estouraram o que ficou conhecido como "escritório central do crime" (Bangu 1). ${ }^{34}$ Este episódio tensionou muito as relações entre setores do MPE e da magistratura com o governo do Estado. O MPE divulgou gravações indicando que Fernandinho Beira-Mar comprava drogas e armas e que, inclusive, adquirira um míssil Stinger. ${ }^{35} \mathrm{~A}$ juíza da $1^{\text {a }}$ Vara Criminal de Bangu, Sonia Maria Gomes Pinto, além de autorizar a revista em Bangu 1, determinou o afastamento provisório do diretor do presídio, Durval Pereira Melo, e a suspensão de agentes penitenciários. A ação não foi comunicada ao governo do Estado. O secretário de Justiça, Paulo Saboya, foi impedido de entrar no presídio durante a operação. ${ }^{36} \mathrm{O}$ presidente do Tribunal de Justiça, Marcus Faver, ao receber o secretário Saboya, sustentou que a ação foi legal, e que não havia necessidade de ser comunicada ao governo. Segundo Faver, como autoridade do sistema penitenciário, Saboya deveria ter acompanhado a operação. Na decisão da juíza não havia, entretanto, qualquer determinação de impedir a entrada de outras autoridades. ${ }^{37}$
Na madrugada de 24 de junho, o prédio da Prefeitura do Rio de Janeiro foi alvo de um atentado. ${ }^{38} \mathrm{O}$ prefeito Cesar Maia pediu a decretação do Estado de Defesa no Rio. ${ }^{39} \mathrm{O}$ presidente Fernando Henrique foi visitar o prédio. A Subsecretaria de Inteligência - SSI da Secretaria de Estado de Segurança chegou a investigar o caso como uma ação "narcoterrorista". Suspeitava-se que a ordem para o ataque tivesse partido do complexo penitenciário de Bangu. $\mathrm{O}$ ato poderia ter sido uma retaliação à escuta telefônica e à vistoria no Presídio de Segurança Máxima Bangu 1 por promotores do Ministério Público Estadual, na semana anterior. De fato, o ataque não teve motivação política; tratou-se de um episódio isolado. ${ }^{40}$ Porém, a partir desse episódio foi criada uma "força-tarefa", ${ }^{41}$ coordenada pelo Ministério da Justiça, com a participação da Secretaria da Receita Federal e do Ministério Público, para combater o crime organizado no Rio. ${ }^{42}$

O motim de 11 de setembro ${ }^{43}$ em Bangu 1, ocorrido a quase um mês das eleições gerais de 15 de outubro, foi um dos momentos mais significativos da luta entre as facções ${ }^{44}$ que controlam o tráfico de drogas no Rio. ${ }^{45}$ Líderes do Comando Vermelho eliminaram quatro chefes do Terceiro Comando e da facção ADA - Amigos dos Amigos pela manhã, ${ }^{46}$ após tentativa frustrada de fuga. ${ }^{47}$

A partir do depoimento de Marcelo Freixo, ${ }^{48}$ que participou da negociação para liberar os reféns, foi possível esclarecer alguns pontos. Havia um plano do grupo ligado ao traficante Uê para exterminar rivais do Comando Vermelho. Os guardas de Bangu 1 teriam sido, portanto, subornados inicialmente por Uê. Porém, um desses guardas passou essas informações para o Fernandinho BeiraMar, que pagou mais pelo plano a ser executado. O traficante Beira-Mar "comprou as chaves da cadeia". ${ }^{49} \mathrm{O}$ objetivo do grupo do CV era fuga. Quando andavam armados no pátio do presídio em direção à porta, foram surpreendidos por um grupo de agentes do SOE - Serviço de Operações Externas do Desipe. Houve troca de tiros e os detentos recuaram para dentro do prédio. E, então, teriam sido eliminados os adversários do Terceiro Comando e da ADA. A seguir, foram pegos oito reféns. Esses fatos ocorreram de manhã bem cedo, antes de 8 h30.

O subsecretário de Segurança Pública, Ronaldo Rangel, afirmou o propósito: "Os bandidos diziam que se houvesse esculacho, ou seja, se a polícia tomasse qualquer atitude mais enérgica, eles iriam acionar bondes de traficantes para espalhar o terror por toda a cidade". ${ }^{50}$

O clima de medo propagou-se pela cidade. ${ }^{51}$ Lojas e escolas em nove bairros ficaram fechadas por dois dias. ${ }^{52}$ 
A governadora Benedita mobilizou-se para transferir Fernandinho Beira-Mar para algum outro estado. O governo federal e governos estaduais hesitavam em colaborar. ${ }^{53}$ A proximidade das eleições de 6 de outubro davam a essas negociações um significado político preciso: os atores políticos usaram o episódio para fixar uma agenda política e estigmatizar o competidor como frouxo no combate ao crime organizado. ${ }^{54}$

O drama de 11 de setembro em Bangu 1 rendeu inúmeros diagnósticos e reflexões sobre a segurança. Roberto Aguiar, secretário de Segurança Pública, ao anunciar que policiais civis e militares assumiriam o presídio em substituição aos agentes penitenciários, afirmou: "Bangu 1 é muito seguro. Seguras não eram as cabeças que estavam lá dentro. Nem a melhor segurança arquitetônica funciona quando a corrupção e a imoralidade estão instaladas. A segurança máxima é possível desde que as pessoas lá dentro queiram o bem da população, não o de seus bolsos". 55

\section{Regime Disciplinar Especial de Segurança: de São Paulo para o Rio}

Após o motim de Bangu 1, houve dentro da cúpula do governo Benedita uma polêmica sobre como reagir à crise. O secretário de Justiça, Paulo Saboya, segundo seu próprio depoimento, foi contrário à implantação da política do cárcere duro. ${ }^{56}$ Como parte do acordo para superar a questão, a penitenciária de Bangu 1 passou para o controle da Secretaria de Segurança Pública. Foi também nomeado o major da Polícia Militar Hugo Freire para dirigir o Desipe. ${ }^{57}$ No dia 16 de setembro foi publicada, no Diário Oficial, a resolução SEJGAB n ${ }^{0} 13,{ }^{58}$ assinada pelo secretário Paulo Saboya, que regulamentou a inclusão, a permanência e a exclusão de presos no RDES. ${ }^{59}$

A resolução estabelece prisão especial para os líderes e integrantes das facções criminosas, bem como para os presos que venham a transgredir, de forma grave, as regras previstas na Lei de Execução Penal e no Regulamento Penitenciário. Esta resolução praticamente acolhe os termos do Regime Disciplinar Diferenciado paulista. ${ }^{60}$

A decisão de enquadrar o detento no RDES pode ser encaminhada pelo diretor de qualquer unidade penitenciária ao secretário de Justiça, que analisará o pedido e dará o veredicto. O tempo de permanência do preso nesse regime é de 180 dias $\left(\operatorname{art} .4^{\circ}\right)$. Em caso de reincidência, o detento poderá ser submetido a 360 dias de reclusão especial. ${ }^{61}$
O secretário Saboya também pretendia limitar o contato entre advogados e seus clientes na prisão. Ele queria criar salas separadas por vidros à prova de bala em todos os presídios do Estado. A Ordem dos Advogados do Brasil - OAB decidiu recadastrar seus 450 mil filiados para banir "falsos profissionais". Até dezembro de 2002, todos os advogados do país tiveram de trocar a carteira de identificação profissional por um documento com tinta antifalsificação e tarja magnética, elaborado pela Casa da Moeda. ${ }^{62}$

Outra medida anunciada na ocasião atingiu os 3.800 agentes penitenciários do Rio: a obrigatoriedade de apresentação de cópia de declaração de Imposto de Renda, do número do telefone celular (com nota fiscal do aparelho), do endereço atualizado e de documentos de propriedade de veículos. O objetivo era saber se o patrimônio dos agentes era compatível com a renda e se eles poderiam estar sendo corrompidos pelos traficantes. ${ }^{63}$

\section{O Dia em que o Rio Parou: 30 de setembro de 2002}

O Rio parou na segunda-feira até na zona sul, apesar de não terem ocorrido depredações nesta parte da cidade. $\mathrm{O}$ cidadão rendeu-se à intimidação dos traficantes de drogas. O comércio fechou inclusive em shoppings, que dispõem de seguranças particulares. O prejuízo foi calculado em R\$ 130 milhões, cerca de metade do faturamento diário da Região Metropolitana. Quarenta bairros foram atingidos pela paralisação. Em todo o Grande Rio, 800 mil passageiros ficaram sem ônibus. O prejuízo das empresas foi calculado em R\$ 2,4 milhões. Universidades como PUC, Estácio de Sá e UniverCidade suspenderam as aulas. Na rede municipal, 22\% das escolas fecharam; entre as escolas particulares, $40 \%$ pararam. ${ }^{64}$

Esta paralisação ocorreu especialmente em áreas consideradas de domínio do Comando Vermelho. ${ }^{65}$ A Secretaria de Segurança estava informada do plano de parar até a zona sul. ${ }^{66}$ Gravações de conversas telefônicas, feitas pelo Ministério Público estadual no dia 17 de setembro de 2002, com autorização judicial, foram entregues ao secretário de Segurança Pública, Roberto Aguiar. ${ }^{67}$

A governadora Benedita, em pronunciamento feito à noite em rede estadual de televisão, afirmava: "O que vivemos no dia de hoje foi a reação desesperada de agentes do crime organizado contra uma política de segurança pública inteligente e bem-sucedida, que em menos de cinco meses prendeu mais de 1.700 pessoas envolvidas 
com o tráfico, entre as quais 50 chefões do crime organizado". ${ }^{68}$

A Secretaria de Segurança anunciou, no mesmo dia, o endurecimento no tratamento dado aos sete presos no Batalhão de Choque da PM: ficariam temporariamente suspensas as visitas dos advogados. ${ }^{69}$ O secretário Roberto Aguiar anunciou que tomaria providências para pôr fim à divisão de presídios entre as facções como Comando Vermelho, Terceiro Comando e Amigos dos Amigos.

\section{Forças Armadas no Primeiro Turno das Eleições}

A governadora Benedita solicitou envio de tropas federais para garantir a ordem nas eleições de outubro. ${ }^{70}$ Havia receio de que os traficantes bloqueassem parte dos morros - impedindo o direito de voto do eleitorado do Rio que vive nestes locais. No dia 5 de outubro, cerca de 11 mil homens do Exército entraram em prontidão. Deste total, 3.000 soldados ocuparam 20 áreas consideradas críticas, como os complexos do Alemão e da Maré.

\section{Rebelião em Bangu 3: Outubro Vermelho}

O plano de fuga incluía a explosão do muro de sete metros do presídio. Haveria então o resgate dos presos por um grupo de 63 homens armados. Era a primeira vez que se tentava um resgate no complexo de Bangu. ${ }^{71}$

A Secretaria de Segurança Pública já sabia do plano de fuga, ${ }^{72}$ segundo autoridades do governo. ${ }^{73}$ Luiz Eduardo Soares $^{74}$ escreveu sobre "quatro novidades em curso", ao comentar a tentativa de resgate em Bangu 3:

- "PCC, de São Paulo, tem procurado desde 2001 associar-se ao Comando Vermelho, ampliando seu poder no crime organizado;

- retorno de Fernandinho Beira-Mar ao Rio de Janeiro, em função de seu poder (está sob seu controle a provisão de drogas para o comércio varejista fluminense), precipitou a luta pela unificação das correntes criminosas;

- a governadora Benedita da Silva não admitiu conciliações com o crime e realizou prisões de lideranças, que estimularam disputas por mercados e territórios; e,

- as principais lideranças criminosas estão alterando o patamar de sua intervenção. Seus últimos movimentos demonstram a intenção de politizar sua inserção na cena pública, transformando o caráter de suas ações e a natureza de sua identidade. Sua nova linguagem é a do terror". ${ }^{75}$

\section{Forças Armadas no Segundo Turno das Eleições}

No dia 16 de outubro, a governadora anunciou que já tinha enviado ao Tribunal Regional Eleitoral - TRE, um pedido formal para que as Forças Armadas integrassem as forças de segurança nas eleições. ${ }^{76}$ Realizou-se uma considerável mobilização policial-militar para prevenir e coibir eventuais ações do crime organizado no segundo turno das eleições presidenciais. ${ }^{77}$ A votação ocorreu sem distúrbios no dia 27 de outubro.

\section{“Cárcere Duro" somente em Bangu 1}

No dia 30 de outubro, o Diário Oficial do Estado do Rio publicou a resolução da Secretaria de Estado de Segurança Pública que restringia regalias dos presos em Bangu 1. ${ }^{78}$ Depois de instalar, no início desse mês, bloqueadores de celular, ${ }^{79}$ o governo petista estabeleceu o uso obrigatório de uniformes de detentos, restrição do número de advogados e de visitas por preso. ${ }^{80}$ De acordo com a resolução $\mathrm{n}^{\circ} 572$, cada preso poderia receber visitas de apenas um advogado credenciado, no máximo por 30 minutos e sempre em dias úteis (art. $8^{\circ}$ ).

As visitas comuns eram autorizadas apenas para pais, mães, esposas, companheiras e filhos dos detentos, duas vezes por semana, respeitando um rodízio que seria definido pelo diretor do Desipe (art. 16 ${ }^{\circ}$ ). Todas as visitas seriam no parlatório, onde presos e visitantes ficariam isolados por um vidro à prova de balas, sem contato físico. ${ }^{81}$

\section{SEGUNDO GOVERNO GAROTINHO: AGORA É ROSINHA}

A governadora Rosinha Garotinho criou, pelo Decreto $\mathrm{n}^{\mathrm{o}}$ 32.621, de 1 de janeiro de 2003, a Secretaria de Administração Penitenciária - SEAP, o que sinalizava a importância que o sistema penitenciário assumira. ${ }^{82}$ Uma das primeiras medidas tomadas pelo secretário Astério Pereira dos Santos foi trazer para a SEAP as casas de custódia e o Presídio Bangu 1, que no governo Benedita estavam subordinados à Secretaria de Segurança Pública.

O secretário Astério Pereira é coronel reformado da PM. Dirigiu o presídio Ary Franco (Água Santa), de 1976 a 1983, e o presídio Candido Mendes (Ilha Grande), em 1981. Posteriormente, Astério tornou-se promotor de Justiça. Na equipe da direção da Secretaria, havia outro promotor de Justiça, Aldney Peixoto, que foi Corregedor das Polícias Unificadas no governo Benedita. Constata-se um 
retorno de membros do Ministério Público Estadual - MPE à direção de assuntos penitenciários, o que era comum no passado. Se a articulação da SEAP com o MPE era feita por gestores do sistema penitenciário, a ligação do secretário com o prefeito do Rio de Janeiro, Cesar Maia, vinha do apoio para empreendimentos de modernização e construção de presídios. De qualquer forma, o secretário Astério não fez parte do grupo de transição do governo Rosinha Garotinho.

O secretário Astério tinha objetivos na administração ${ }^{83}$ e um plano de ação, mas não dispunha de recursos para implementá-los. ${ }^{84}$ Quanto à disciplina que pretendia impor ao sistema de carceragem, não havia diferença na prática entre o que se afirmava na sua gestão e o que foi imposto no governo Benedita. $\mathrm{Na}$ verdade, havia mais continuidade na política penitenciária adotada então do que mudança em relação ao governo petista.

$\mathrm{O}$ endurecimento disciplinador nos cárceres, conforme foi exposto anteriormente, foi realizado no governo Benedita. O secretário Astério reeditou o RDES, através da Resolução SEAP/GAB n ${ }^{\circ} 8$ de 7 de março de $2003 .{ }^{85}$ A Resolução SEAP n ${ }^{\circ} 13$ de 28 de março de 2003 disciplinou o ingresso de pessoas e de veículos no interior dos estabelecimentos. A Resolução SEAP n ${ }^{\circ} 14$ de 7 de abril de 2003 estabeleceu normas para organizar e garantir o acesso de advogados aos seus clientes presos em Bangu 1. ${ }^{86}$ A Resolução $n^{\circ} 26$ de 7 de julho de 2003 disciplinou a entrada de alimentos e objetos trazidos pelos familiares e por via postal, nas visitas às unidades prisionais. ${ }^{87}$

Segundo o secretário de Administração Penitenciária, Astério Pereira dos Santos, em maio de 2003, havia 26 mil presos acautelados no Estado do Rio. Desses, 18 mil estavam no sistema (penitenciárias e casas de custódia), mas 8 mil permaneciam em carceragem policial. Havia ainda cerca de 70 mil mandados judiciais de prisão não cumpridos. ${ }^{88}$

\section{Segunda-feira sem Lei: a Segunda Mobilização pelo CV, Agora Violenta}

A semana do Carnaval de 2003 começou com violência, que dessa vez atingiu a zona sul do Rio. ${ }^{89}$ Três bombas de fabricação caseira explodiram na Avenida Vieira Souto, em Ipanema. Janelas de prédios ficaram estilhaçadas. ${ }^{90}$ Em Botafogo, houve arrastões, um supermercado foi atacado e um coquetel molotov foi atirado contra um ônibus da linha 410 (Usina-Jardim) cheio de passageiros. Uma senhora de 70 anos foi queimada nesse ataque, vindo a falecer dias depois. Este episódio do ônibus em chamas ocorreu no ponto da Rua São Clemente, em frente ao Morro Dona Marta, a menos de 100 metros do $2^{\circ}$ BPM (Botafogo). É provável que este acontecimento tenha mudado a percepção de muitos cidadãos sobre a situação da cidade em face do terrorismo dos narcotraficantes.

O CV distribuiu em vários bairros uma carta onde assumiu a autoria dos atos violentos. A polícia deteve 45 pessoas suspeitas por envolvimento no ataque a 38 ônibus e na distribuição de cartas com ameaças a comerciantes. Segundo o chefe de Polícia do Rio, essas pessoas seriam autuadas por associação ao tráfico. O crime é inafiançável e tem pena prevista de três a 10 anos de prisão. Era um notável endurecimento na repressão policial. ${ }^{91}$

No dia da mobilização criminosa, o secretário de Administração Penitenciária, Astério Pereira dos Santos, suspendeu as regalias dos 24 presos da facção criminosa $\mathrm{C} \mathrm{V}$ no Presídio Bangu 1. Pela manhã, agentes do Serviço de Operações Especiais recolheram dos internos aparelhos de rádio e televisão. Fernandinho Beira-Mar passou a tarde daquele dia confinado. Durante os 15 dias seguintes, o grupo não teve direito a visita íntima e banho de sol.

$\mathrm{Na}$ terça-feira, 25 de fevereiro, um hipermercado foi metralhado na Penha. Tiros também atingiram um shopping e dois postos de gasolina. Mais quatro ônibus foram incendiados em pontos diferentes da cidade e da Região Metropolitana. O governo estadual reagiu, anunciando a Operação Rio Seguro. Na quarta-feira, os policiais estavam nas ruas, com o apoio da Guarda Municipal. ${ }^{92}$ O secretário de Segurança, Josias Quintal, afirmou, então, energicamente: "Vamos partir para dentro. Se tiver que ter conflito armado, que tenha. E, se alguém tiver que morrer que morra". ${ }^{93}$

Segundo gravações feitas com autorização da Justiça pela Polícia, Beira-Mar teria dito no dia 26 de fevereiro: "Perdi. Mas eles vão dar continuidade ao trabalho. Vão zoar esse sistema. Não adianta me levar". ${ }^{94}$

Na quinta-feira, 27 de fevereiro, Fernandinho Beira-Mar foi transferido para o presídio de segurança máxima de Presidente Prudente, no interior de São Paulo, onde deveria permanecer por 30 dias. No dia seguinte, em ação audaciosa, traficantes fecham a Avenida Brasil por uma hora.

\section{Operação Guanabara: as Forças Armadas na Segurança ao Carnaval}

No sábado de Carnaval, três mil homens do Exército ocuparam as principais vias de acesso à cidade. Era a Operação Guanabara, que contava ainda com 34 mil policiais 
civis e militares e 4.500 guardas municipais. ${ }^{95} \mathrm{O}$ turismo não chegou a sofrer com as ações terroristas dos traficantes. Houve um faturamento superior ao ano anterior. ${ }^{96}$ Porém, mesmo com o reforço do policiamento, os homicídios e assaltos a ônibus aumentaram em relação ao ano de 2002. ${ }^{97}$ Ocorreu também uma tragédia: um professor de inglês foi morto por soldados do Exército por não ter parado num bloqueio, na antiga Avenida Automóvel Clube. ${ }^{98}$ Apesar desse caso isolado, o governo estadual pediu ao governo federal que mantivesse a Operação Guanabara por mais 30 dias. ${ }^{99}$ Em setembro de 2003, foi noticiado que o Exército já tinha um manual de 80 páginas, onde constam novas instruções para o treinamento de tropas que atuariam como polícia contra o crime organizado, em cidades como o Rio. ${ }^{100}$

\section{Dois Juízes de Varas de Execuções Penais Assassinados: Novo Impulso à Legislação do "Cárcere Duro"}

No dia 14 de março, o juiz da Vara de Execuções Penais de Presidente Prudente, Antônio José Machado Dias, foi executado em São Paulo. A OAB de São Paulo acusou imediatamente a quadrilha de Fernandinho Beira-Mar pelo assassinato. Habitantes de Presidente Prudente exigiram a transferência do traficante. ${ }^{101}$ Estava consolidada a fama de Beira-Mar como a personificação do terror. O jornal O Globo, em editorial intitulado "Ao confronto", afirmava que: "Chegou a hora de reagir com o máximo rigor. (...) A guerra já começou". ${ }^{102}$

A morte do juiz paulista apressou o debate sobre alterações na Lei de Execuções Penais para tornar mais rigo- roso o tratamento dado nas penitenciárias aos presos ligados ao crime organizado. ${ }^{103}$ Deu-se início também ao debate sobre como proteger os juízes. Foi sugerida a adoção do sistema Juiz Sem Rosto, que impede que o criminoso saiba o nome do juiz que lhe aplicou a pena. $\mathrm{O}$ secretário de Administração Penitenciária, Astério Pereira, era favorável à adoção desse sistema, e propunha que fosse estendido aos promotores do Ministério Público. ${ }^{104}$

No dia 24 de março, foi executado em Vitória o juiz da Vara de Execuções Penais, Alexandre Martins de Castro Filho, que estava sendo ameaçado pelo crime organizado. $\mathrm{O}$ debate legislativo acelerou-se no Congresso. No dia $1^{\circ}$ de abril, a Câmara dos Deputados aprovou, em votação simbólica, projeto modificando a Lei de Execuções Penais - LEP e aumentando o rigor do regime carcerário para presos de alta periculosidade. O projeto estendia a pena de isolamento em cela individual de 30 dias, como estabelecido na LEP, para até 360 dias. ${ }^{105}$ No Senado, a tendência ao endurecimento ${ }^{106}$ no regime carcerário era clara, com a proposta de um "regime disciplinar de segurança máxima".

A tendência do debate legislativo era, portanto, nitidamente pelo endurecimento. O projeto de lei do governo federal criando o Regime Disciplinar Diferenciado para tratar com maior rigor presos considerados perigosos foi aprovado na Câmara dos Deputados. No Senado, a proposta foi analisada pela Subcomissão de Segurança Pública e pela Comissão de Constituição, Justiça e Cidadania - CCJ, onde foi incluído um novo regime diferenciado: o Regime Disciplinar de Segurança Máxima - RDSM. No Quadro 1, verificam-se algumas diferenças entre os dois regimes. ${ }^{107}$

QUADRO 1

Diferenças entre Regimes Disciplinares

\begin{tabular}{|c|c|}
\hline Regime Disciplinar Diferenciado (1) & Regime Disciplinar de Segurança Máxima (2) \\
\hline $\begin{array}{l}\text { - Atinge o preso provisório que cometa crime doloso ou promova a subversão da } \\
\text { ordem ou da disciplina interna do estabelecimento penitenciário; o preso ou } \\
\text { condenado que apresente alto risco para a ordem e a segurança do estabele- } \\
\text { cimento penal ou da sociedade; ou o preso provisório ou condenado sobre o } \\
\text { qual recaiam suspeitas fundadas de envolvimento ou participação em organi- } \\
\text { zação criminosa; } \\
\text { - } \quad \text { Duração máxima de } 360 \text { dias, que podem ser prorrogados até o limite de um } \\
\text { sexto da pena aplicada; } \\
\text { - } \quad \text { Recolhimento em cela individual; } \\
\text { - Visitas semanais de duas pessoas, sem contar as crianças, com duração de } \\
\text { - duas horas; } \\
\text { Banho de sol de até duas horas por dia. }\end{array}$ & $\begin{array}{l}\text { - } \quad \text { Atinge o preso provisório ou condenado sobre o qual recaiam indícios funda- } \\
\text { - } \quad \text { dos de envolvimento com organização criminosa; } \\
\text { - } \quad \text { Recolhimento em cela individual; } \\
\text { - } \quad \text { Visitas mensais, limitadas a, no máximo, dois familiares, separados por vidro e } \\
\quad \text { com comunicação via interfone, com filmagem e gravação; } \\
\text { - } \quad \text { Banho de sol de até duas horas por dia; } \\
\text { - } \quad \text { Proibição de entrega de alimentos ou bebidas; } \\
\text { - } \quad \text { Proibição de telefones, som, televisões e rádios; } \\
\text { - } \quad \text { Proibição de comunicação com outros presos e com agentes penitenciários nos } \\
\quad \text { banhos de sol; } \\
\text { - } \quad \text { Monitoramento completo do preso; } \\
\text { - Contatos mensais com advogados; } \\
\text { - Prisão em estabelecimento penal localizado em estados distantes do local de } \\
\quad \text { influência da respectiva organização criminosa. }\end{array}$ \\
\hline
\end{tabular}

(1) De acordo com o projeto de lei da Câmara no 12 de 2003. (2) De acordo com o relatório do senador Tasso Jereissati aprovado pela CCJ. 


\section{O Terceiro Protesto Violento}

A terceira mobilização criminosa do Comando Vermelho ocorreu segunda-feira, 7 de abril. Não se tratava de um incidente prisional propriamente dito, pois os atos criminosos foram desenvolvidos fora do espaço carcerário. Porém, a ligação entre a paralisação que atingiu 10 bairros no Rio, chegando a São Gonçalo, e as lideranças encarceradas constituía o mais importante aspecto da situação.

Os detentos avisaram aos parentes que não queriam receber visita no domingo, 6 de abril, e que negociariam por melhores condições no cárcere. O motivo: as novas normas da Secretaria de Administração Penitenciária como o RDES e as normas que regulavam as visitas dos advogados.

Setores de inteligência das polícias Civil e Federal tinham notícia de que o CV pretendia fechar o comércio, atacar prédios públicos e impedir a saída dos ônibus das garagens das empresas. A Polícia Militar foi colocada de prontidão, e o Batalhão de Operações Especiais - Bope e o Batalhão de Choque permaneceram em frente aos complexos penitenciários de Bangu e de Frei Caneca para invadir as unidades em caso de rebelião. ${ }^{108}$ Mas não houve a rebelião que as autoridades esperavam.

Aconteceu a paralisação no comércio, repetindo o que já ocorrera uma semana antes, em menor escala. ${ }^{109}$ Dessa vez foi distribuída uma carta atribuída ao traficante Isaías do Borel. O texto continha ameaças de desencadear uma "revolução extraordinária", "seqüestrando autoridades" e "desarticulando a Segurança Pública". ${ }^{110}$ Outro texto foi divulgado ${ }^{111}$ pela Internet para os jornais, reivindicando melhorias nas condições carcerárias. Como se não bastasse esse conflito com os presos, os agentes penitenciários decidiram entrar em greve por tempo indeterminado por razões salariais. ${ }^{112}$

No dia 29 de maio, o seqüestrador Sussuquinha realizou uma fuga que constrangeu a cúpula da segurança do Rio: saiu pela porta da frente do Batalhão de Choque da PM, no centro do Rio. ${ }^{113}$ Esse era supostamente o último reduto de "segurança máxima", usado após o episódio de Bangu 1, em 11 de setembro de 2002.

\section{A Greve de Fome do Comando Vermelho}

A greve de fome começou à zero hora de segunda-feira, 17 de agosto de 2003, um dia após as visitas mais concorridas. Todo o movimento parecia ter sido preparado com grande antecedência, mas precipitado com um dramático evento em Bangu 3.
Na quinta-feira, 14 de agosto, houve uma revista geral. Os presos estavam sob a vigilância do SOE - Serviço de Operações Externas. Quando o superintendente do Sistema Penitenciário, tenente-coronel Cid Souza Sá, que dirigia a operação, foi chamado para ver um laptop que havia sido descoberto, a tensão aumentou entre os presos e os agentes do SOE. Cinco detentos foram atingidos por tiros de balas de borracha, pelas costas e de bem perto. ${ }^{114}$

O Conselho da Comunidade da Comarca do Rio de Janeiro $^{115}$ foi chamado para ajudar a buscar uma solução negociada para o movimento de protesto pacífico. ${ }^{116}$ Depois de cinco dias de greve, quando o movimento já mobilizava cerca de 10 mil presos ligados ao CV, conseguiu-se um acordo. Foram atendidas apenas as reivindicações administrativas que tinham pleno respaldo legal. No entanto, o movimento também protestava contra propostas:

- de se transferir para a esfera federal as penitenciárias de Bangu 1 e Bangu 3;

- de submeter os presos dessas unidades às punições rígidas, cruéis, estabelecidas pelo novo regime disciplinar especial (RDES), aliás em total afronta aos princípios dos Direitos Humanos. ${ }^{117}$

O texto do manifesto do Comando Vermelho afirmava que o RDES seria aplicado a Bangu 1 e Bangu 3. Mas, o RDES foi aplicado ${ }^{118}$ apenas em uma galeria de Bangu 1. Aparentemente, as lideranças do CV temiam que o RDES viesse a ser executado também em Bangu 3.

\section{CONCLUSÃO}

O medo é uma prisão que vem de todos os lados Guimarães Rosa

As resoluções dos secretários estaduais que impuseram a política do "cárcere duro" para os líderes do CV permanecerão vigentes, provavelmente até que o Congresso Nacional, num futuro próximo, dê um embasamento legal para as providências já tomadas desde o governo Benedita. ${ }^{119}$ A validade jurídica dessas medidas poderá ainda ser questionada judicialmente no Rio. ${ }^{120}$ No entanto, a ação conjunta das autoridades fluminenses e do governo federal para evitar a transferência de Fernandinho Beira-Mar, que cumpre pena no presídio de Artur Bernardes, para o Bangu 1 indica que há um consenso de que a certos delinqüentes deve-se impor o regime de "cárcere duro". ${ }^{121}$ 
Mas é precisamente nesse ponto que se revela um grave problema. No sistema penitenciário fluminense, a efetividade desta política de castigo seria, no mínimo, limitada pelo déficit institucional ${ }^{122}$ e pela corrupção existente, ${ }^{123}$ como evidenciou o episódio de 11 de setembro em Bangu 1, e na fuga do seqüestrador Sussuquinha do Batalhão de Choque da PM, no centro do Rio. Haveria, portanto, a versão carioca desta política: "cárcere duro" sem vigilância máxima. ${ }^{124}$

Por último, fica a indagação por que o CV decidiu comandar uma greve de fome pacífica de dentro de Bangu 3, um presídio que já havia sido alvo de duas importantes rebeliões armadas ${ }^{125}$

A greve de fome foi um ensaio geral. A liderança pôde verificar o alcance do seu controle, inclusive demonstrando a disciplina de seus soldados diante da fome. Disseminou dentro do sistema carcerário suas orientações. Nada disso é casual ou novo. O CV tem uma tradição de greve de fome, desde a Ilha Grande. Devido ao número enorme de jovens detentos ligados ao $\mathrm{CV}$, as lideranças podem ter vislumbrado a necessidade de socializá-los com um exercício organizado para todos da "federação". O significado da greve dos 10 mil talvez esteja nesta reconstrução da identidade dos guerreiros revoltados pelas "injustiças" do sistema penitenciário que não funciona de acordo com as leis do Estado. É a visão de um "Estado de desordem" porque produz regularmente injustiças para os excluídos. ${ }^{126}$ Esta perspectiva politiza a atuação da rede criminosa Comando Vermelho ao vinculá-la às desigualdades sociais urbanas. E, por isso, aproxima-nos mais de uma situação de convulsão social.

Será que a "cultura do controle"127 por si só terá mecanismos para conter essa desordem social que se prepara e se anuncia? ${ }^{128}$

\section{NOTAS}

1. Sobre a abordagem da "história do presente", ler: Foucault (2003a:29). Ler ainda sobre prisões em: Foucault (2003b). Para o uso dessa abordagem, conforme usada nesse estudo, ler: Garland (2001:126). O presente estudo é complementado pelo artigo do Caldeira (2003:91-115).

2. O governo italiano criou uma legislação de emergência em sua luta contra o crime organizado e o terrorismo. Introduziu medidas duras de disciplina carcerária. "O governo construiu os chamados Cárceres Especiais, cujas normas de disciplina se assemelham às da Penitenciária de Segurança Máxima de Presidente Bernardes, no interior paulista. O capo dei tutti capi (chefe dos chefes mafiosos) Totó Riina, preso em 1993, está até hoje detido nesse regime de "cárcere duro": não tem direito a visita íntima, não pode receber comida da família e fica sepa- rado dos visitantes por vidros à prova de balas - a conversa ocorre por telefone. Nem os mafiosos em liberdade condicional escaparam da linha dura: passaram a ser monitorados por pulseiras ou tornozeleiras eletrônicas.” Cf. “'Cárcere duro’ estimulou delação na Máfia: Sistema foi adotado após o assassinato dos juízes Giovanni Falcone e Paolo Borselino", O Estado de S.Paulo, 30/03/2003. Disponível em:

$<$ http://www.estado.estadao.com.br/editorias $/ 2003 / 03 / 30 /$ cid021.html>. Acesso em: 30 set. 2003.

3. Agradeço à Tania Kolker, do Grupo Tortura Nunca Mais, que me alertou para essa exclusão da discussão sobre tortura e maus-tratos de presos neste estudo.

4. "Traficante nega plano para matar Maia", Folha de S.Paulo, caderno Cotidiano, 15/09/1995, p.3.3.

5. "Rio não vai investigar denúncias de Escadinha", O Estado de S.Paulo, caderno Cidades, 10/02/1998. Disponível pela data em:

$<$ http://www.estado.estadao.com.br/pesquisa/procura.html $>$. Acesso em: 30 set. 2003.

6. Ler: "Polícia descobre túnel para fuga em Bangu 3", O Estado de S.Paulo, 23/01/2003. Disponível em:

$<$ http://www.estado.estadao.com.br/jornal/01/01/23/news303.html>; "Túnel começou a ser planejado a 1 ano", Estado de S.Paulo, 24/01/ 2001. Disponível em:

$<$ http://www.estado.estadao.com.br/jornal/01/01/24/news152.html >. Acesso em: 30 set. 2003.

7. "25 mil presos fazem motins em 19 cidades", Folha de S.Paulo, caderno Cotidiano, 19/02/2001, p.C1; "Rebelião deixa 16 mortos e revela falência do sistema penitenciário", $O$ Globo, 20/02/2001, p.1. No programa Domingo Legal, do Sistema Brasileiro de Televisão SBT, um preso falou ao vivo, da Casa de Detenção, pelo celular, com o apresentador Gugu Liberato. Cf. "'Domingo Legal' causa polêmica”, Estado de S.Paulo, 20/02/2001, p.C-5. Pelo menos 32 celulares foram apreendidos em 15 presídios, no interior de São Paulo, que participaram da rebelião convocada pelo PPC no domingo, 18 de fevereiro de 2001. É um número muito pequeno de celulares apreendidos, o que sugere que as operações varredura não foram eficientes. Os celulares entram nas cadeias levados pelos visitantes (incluindo os advogados), ou pelos agentes penitenciários. Na época, a "propina" para facilitar a entrada de um celular nos presídios paulistas variava de R\$ 300 a R\$ 600. Cf. "Revista detecta 32 celulares", Folha de S.Paulo, caderno Cotidiano, $21 / 02 / 2001$, p.C3. Um preso foi fotografado falando tranqüilamente em seu celular, sentado na janela da sua cela na Casa de Detenção de São Paulo, meia hora após encerrada a megavarredura realizada pela Polícia Militar. Esta foto foi estampada na primeira página dos jornais. Cf. "Presos desafiam a polícia: varredura nos presídios não impede o uso de celulares", $O$ Globo, 21/02/ 2001. Ler ainda: "Celulares, a principal arma para as rebeliões", $O$ Globo, 2. ed., caderno O País, 20/02/2001, p. 9. A maior rebelião na história do país custou no mínimo R\$ 7 milhões ao governo do Estado de São Paulo, apenas em reformas de prédios. Cf. "Rebelião deixa prejuízo de R\$ 7 mi ao Estado", Folha de S.Paulo, caderno Cotidiano, $15 / 03 / 2001$.

8. Ler: "Celular liberado em Bangu: Teste mostra que bloqueadores de sinais não funcionam em quatro presídios", O Globo, caderno Rio, 7/ 09/2003, p.20.

9. “A polícia já ouviu uma testemunha que levantou suspeitas sobre um dos encarregados da investigação, um oficial da PM. Ele teria reclamado de estar perdendo R\$ 1 milhão por mês com a ação moralizadora de Sidneya." Cf. "OAB investiga 130 advogados por ligações com tráfico: suspeitos foram listados pela diretora assassinada de Bangu 1", O Globo, 8/10/2000, p.1.

10. "Existem 1.150 agentes penitenciários no Estado do Rio. Eles são responsáveis pela vigilância de 16 mil presos e recebem um salário líquido de R\$1.060." Cf. "Salário acima de R\$1 mil”, Jornal do Brasil, caderno Cidade, 7/9/2000, p.15.

11. A política de abolição de privilégios e da corrupção dentro dos presídios, implementada pelo secretário Pinaud, seria, de acordo com 
as entidades que o apóiam, do mesmo modo que o Conselho da Comunidade e a Comissão de Direitos Humanos da Assembléia Legislativa do Rio de Janeiro - Alerj, o motivo da rejeição por parte dos agentes penitenciários que pediram sua saída. Cf. "Sidneya passou a ser a bola da vez", Jornal do Brasil, caderno Cidade, 7/09/2000, p.16.

12. Agentes do SOE - Serviço de Operações Externas armados até com granadas, policiais do BOPE - Batalhão de operações Especiais, Getam - Grupamento Tático-Móvel e do $14^{\circ}$ BPM (Bangu) foram acionados. Cf. "Movimento durou pouco", Jornal do Brasil, caderno Cidade, 7/ 09/2000, p. 15 .

13. "Greve de agentes provoca rebelião de presos", Folha de S.Paulo, caderno Cotidiano, 07/09/2000, p.C1.

14. A proposta gerou protestos de juristas e de entidades ligadas à defesa dos direitos humanos. "É uma solução péssima. Vamos voltar a assistir a uma situação conflituosa entre guarda e preso", disse o jurista Augusto Thompson, ex-diretor-geral do Desipe, que assumiu o sistema penitenciário após um período em que a administração das cadeias, durante o governo Faria Lima, esteve nas mãos da PM. "Muitos agentes passaram a se considerar policiais e até a prestar serviços na segurança privada. O resultado foi um fracasso", avaliou. Cf. "Desipe com Segurança", Jornal do Brasil, 1/07/2001. Disponível em: $<$ http://jbonline.terra.com.br/jb/papel/cidade/2001/06/30/ jorcid20010630013.html>.

15. "Governo reforça segurança em presídios no Rio", O Estado de S.Paulo, caderno Cidades, 20/02/2001, p.C5.

16. "Para evitar revolta, facções são separadas em galerias", O Estado de S.Paulo, caderno Cidades, 20/02/2001, p.C5.

17. 'PCC ameaça governo com 'atos terroristas': fundador da facção diz que grupo tem coligação com Comando Vermelho e que principais líderes estão presos", Folha de S.Paulo, caderno Cotidiano, 2/03/2001, p.C3.

18. "O estatuto do PCC", Folha de S.Paulo, caderno Cotidiano, 2/03/ 2001, p.C-3. A íntegra do estatuto do PCC está em: "O estatuto que deu origem ao PCC", O Estado de S.Paulo, caderno Cidades, 21/02/ 2001, p.C-3. "O PCC é a maior facção do sistema penitenciário em São Paulo, com cerca de seis mil membros. É acusado de ter sido responsável pela morte de pelo menos cem pessoas nos últimos dois anos. Tem braços também fora das cadeias. Extorque dinheiro de presos e chantageia seus parentes, planeja assaltos fora dos presídios, faz tráfico de drogas e resgate de presos". Cf. "Saiba mais sobre o PCC", $O$ Globo, 2. ed., caderno O País, 20/02/2001, p.9. O secretário da Segurança Pública do Estado do Rio, coronel Josias Quintal, afirmou que o PCC tentou montar "um braço" no Rio. A tentativa teria ocorrido quando três líderes da organização foram para presídios do Rio. O mais importante era José Márcio Felipe, o Geleião, um dos principais articuladores da megarrebelião de fevereiro de 2001, que ficou preso em Bangu 1. Segundo apurou-se em investigações policiais, Geleião iniciou entendimentos com líderes do CV, como Márcio Nepomuceno, o Marcinho VP, para uma ação conjunta entre as facções. O secretário avaliou que a iniciativa "não prosperou", mas via alguma influência do PCC nos ataques contra a polícia do Rio, que começaram a aumentar desde 2001. "PCC tentou criar 'braço no Rio, diz secretário", Folha de S.Paulo, caderno Cotidiano, 12/03/2002.

19. Divisão de Captura e Polícia Interestadual.

20. Essa operação de resgate de presos lembra ações do PCC em São Paulo. A polícia sabia que o resgate estava sendo preparado. Na Polinter, estavam 1.040 homens em um espaço projetado para 350 presos. Ler sobre o episódio: "Ação audaciosa no Rio liberta 14 traficantes ligados a Beira-Mar: Derrubaram parede, seqüestraram ônibus e fortemente armados resgataram os traficantes, que estavam detidos na Polinter", Jornal da Tarde, 30/10/2001. Disponível em:

<http://www.jt.estadao.com.br/editorias/2001/10/30/ger025.html>. Acesso em: 30 set. 2003.

Sobre operações de resgate e fugas organizadas pelo PCC, ler: "Fundo do crime financia fugas em SP: Carcereiros e agentes penitenciários recebem até R\$ 30 mil para facilitar a abertura de celas para os detentos", Folha de S.Paulo, caderno Cotidiano, 15/07/2001, p.C1.

21. "PCC planejava seqüestrar no Rio: polícia prende grupo que pretendia capturar secretário para exigir libertação de cúmplices", $O$ Globo, 2. ed., caderno Rio, 8/12/2001, p.14.

22. Misael Aparecido da Silva reforçava a aliança do PCC com o CV e defendia ações conjuntas. Em carta de nove páginas apreendida pela polícia, Misael propõe a realização de um "megaevento nacional", ou seja, uma rebelião em todas as cadeias do país, fazendo funcionários reféns. Na carta, ele explica que para o megamovimento ter sucesso é preciso seqüestrar deputados e senadores do PSDB e do PFL, além de jornalistas. Misael diz ainda que o megaevento pode ser pacífico ou radical. Ele acrescenta que o êxito da missão depende da ajuda em dinheiro do Comando Vermelho: "Seja qual for o método, nós vamos precisar de uma ajuda financeira do C.V. que está bem mais estruturado financeiramente do que nós". "Governo investiga carta da facção", Diário de S.Paulo, 9/03/2002. Disponível pela data em:

$<$ http://www.diariosp.com.br/>.

23. Outra reivindicação do "alto comando" do PCC é o fim dos maustratos à população carcerária. Os líderes defendem a extinção do Regime Disciplinar Diferenciado - RDD adotado nos anexos das Penitenciárias de Avaré I e na Casa de Custódia e Tratamento de Taubaté. Cf. "Facção comandou motins em SP a partir do Rio" Diário de S. Paulo, 20/02/2002. Disponível pela data em:

$<$ http://www.diariosp.com.br/>.

24. Cf. "Internos perigosos podem ter regime diferenciado", Jornal da Tarde, 23/01/2003. Disponível em:

$<$ http://www.jt.estadao.com.br/editorias/2003/01/23/ger017.html >. Acesso em: 30 set. 2003. Em São Paulo, discute-se a necessidade de adotar um RDD também para os menores infratores. Jornal da Tarde, 23/01/2003.

25. Outdoor da revista Veja anunciando o motim de 11 de setembro de 2002 em Bangu 1.

26. A vice-governadora Benedita recebeu um governo praticamente sem nenhuma capacidade de investimento. O governador Garotinho havia comprometido, em apenas três meses de 2003, 55\% dos cerca de $\mathrm{R} \$ 2$ bilhões do orçamento destinado a investimentos. Cf. "Benedita terá pouco dinheiro para investir: Estudo entregue à equipe de transição mostra que atual governo já comprometeu 55\% dos R $\$ 2$ bilhões disponíveis", O Globo, 2. ed., caderno Rio, 18/03/2002, p.18.

27. O ex-secretário de Direitos Humanos e Sistema Penitenciário, João Luiz Duboc Pinaud, negou que a transferência de Beira-Mar tenha sido negociada com o Estado. As autoridades de segurança temiam que a presença do bandido provocasse aumento da violência, com o acirramento da disputa pelo poder do tráfico nas favelas. Ler: Jornal do Brasil, 27/04/2002, p.1 e 15. Disponível pela data em: $<$ http://www.radiobras.gov.br/anteriores/2002/sinopses_2704.htm>.

28. Ler: Jornal do Brasil, 29/04/2002, p.13. Disponível pela data em: $<$ http://www.radiobras.gov.br/anteriores/2002/sinopses_3004.htm>.

29. Dentro do conceito de "incidentes prisionais" estão contidos: fugas, evasões e tentativas de fuga; movimentos reivindicatórios; e motins ou rebeliões. Sobre o assunto ler: Ilanud (1998).

30. Comando Vermelho (CV), Rogério Lemgruber (RL), o Bagulhão, um dos fundadores da facção Paz e Justiça (PJ), lema da facção. Cf. "Ataques cresceram na atual gestão", Folha de S.Paulo, caderno Cotidiano, 17/10/2002, p.C4.

31. "Benedita recusa ação federal na segurança do Rio: Governadora diz que polícias podem cumprir a missão", Jornal do Brasil, 17/05/ 2002, p. 1 .

32. Sobre o caso Tim Lopes, ler: Souza (2002).

33. "FH: crime organizado é inimigo número 1 do país", O Globo, caderno Rio, 21/06/2002, p.15. 
34. Foram apreendidos sete celulares, carregadores, estoques, $\mathrm{R} \$ 1.100$ em espécie, balas calibre 38, 300 gramas de maconha, que estavam num isopor junto com as quentinhas dos presos. Cf. "Saiba mais sobre a central do tráfico em Bangu 1", O Globo, 2. ed., caderno Rio, 19/06/ 2002, p. 14 .

35. "Beira-Mar negociou compra de mísseis iguais aos de Bin Laden: Ação fulminante de juíza e promotores surpreende autoridades e bandidos em Bangu 1", O Globo, 19/06/2002, p.1.

36. "Juíza afasta diretor e suspende agentes: Secretário de Justiça é impedido de entrar no presídio durante operação e governadora defende pedido de desculpas", $O$ Globo, 2. ed., caderno Rio, 19/06/2002, p. 16.

37. "Presidente do TJ diz que ação foi legal", O Globo, 2. ed., caderno Rio, 19/06/2002, p.16.

38. "Atentado com 200 tiros desafia poderes no Rio: Sede da prefeitura é atacada de madrugada, em nova ação do crime organizado no estado," O Globo, 25/06/2002, p. 1. "Cinqüenta e cinco janelas de 30 salas foram quebradas pelos tiros e 275 cápsulas de fuzil calibre 762 foram encontradas. Cf. "Atentado à prefeitura do Rio: 275 tiros e 2 granadas", O Estado de S.Paulo, caderno Cidades, 25/06/2002. Disponível em:

$<$ http://www.estado.estadao.com.br/editorias/2002/06/25/ cid027.html>. Acesso em: 30 set. 2003.

39. "Prefeito pede decretação de estado de defesa: Esta e outras propostas serão discutidas hoje em Brasília em reunião com o presidente Fernando Henrique", $O$ Globo, 2. ed., caderno Rio, 25/06/2002, p.17.

40. Atualmente, avalia-se que o ataque foi motivado pela apreensão de drogas e dólares de traficantes do Morro de São Carlos, que estavam escondidos num depósito de obras da Prefeitura. Em represália à atuação da Comlurb que levou o material, traficantes ligados ao CV teriam disparado contra o prédio.

41. A Polícia Federal pediu ao Ministério da Justiça R\$ 1,5 milhão para financiar as ações integradas no Rio até o final de 2002. Cf. "Verba para força-tarefa", O Globo, 3. ed., caderno Rio, 8/08/2002, p.27.

42. O ministro da Defesa, Geraldo Quintão, insistiu que o apoio das Forças Armadas seria apenas logístico e de inteligência. Ele afirmou que a Constituição não permite atuação mais ampla. "Acessos ao Rio serão vigiados por força-tarefa: Governadora Benedita da Silva (PT) aceitou as dez medidas propostas pelo presidente", O Estado de S.Paulo, caderno Cidades, 27/06/2002 Disponível em:

$<$ http://www.estado.estadao.com.br/editorias $/ 2002 / 06 / 27 /$ cid046.html>. Acesso em: 30 set. 2003.

43. "Beira-Mar assume comando do poder paralelo e aterroriza o Rio: Após chacina em Bangu 1, tráfico metralha escolas, invade supermercado e fecha lojas em 9 bairros", $O$ Globo, 12/09/2002, p.1.

44. No início do ano, a guerra já era acirrada. "Três facções disputam o controle da venda de drogas, que rende R\$12,5 milhões por dia só nas áreas de conflito. O Comando Vermelho vem perdendo espaço para o Terceiro Comando, que tem apoio da ADA - Amigos dos Amigos. A guerra mobiliza 8.500 homens". Cf. "Guerra de facções do tráfico no Rio envolve 8.500 homens", Extra, 20/01/2002, p.1.

45. Foi também um marco na escalada de intimidação sobre a cidade do Rio. "O temor de uma reação violenta do crime organizado, que mantém domínio sobre várias favelas e morros da cidade, levou o carioca a sair mais cedo do trabalho e a evitar alguns trajetos. Algumas escolas e até universidades liberaram seus alunos". Cf. "Ameaças e boatos espalham medo por toda a cidade: Escolas e universidades fecham as portas mais cedo e empresas de ônibus resolvem mudar seus itinerários", $O$ Globo, 2. ed., caderno Rio, 12/09/2002, p.16.

46. O Terceiro Comando e o ADA mantinham um pacto de não agressão. Após o evento, a aliança continuou. Ler: "Ex-fuzileiro na escala de poder", O Dia, caderno Polícia, 13/09/2002, p.9.
47. O depoimento de Marcelo Freixo, em que se baseia a apresentação dos fatos seguintes, pode ser contrastada com a versão apresentada pelo secretário de Justiça, Paulo Saboya. Ao ser indagado em entrevista "Por que o governo negociou em vez de invadir Bangu 1?”, ele respondeu: "eles não queriam negociar nada. Não queriam fugir. Fizeram tudo isso para executar os inimigos. Basta ver que o vice-diretor do Desipe e um representante da Comunidade entraram lá desarmados. (...) Foram corajosos e saíram ilesos. Essa rebelião tem pontos nebulosos.” Cf. "O maior chefe é Marcinho VP: Secretário de Justiça diz que demissão do Diretor do Desipe foi desnecessária", $O$ Globo, 2. ed., caderno Rio, 16/09/2002, p.13.

48. Depoimento público, gravado no dia 5 de setembro de 2003 na Universidade Candido Mendes-Ipanema. Marcelo Freixo participou de todas as negociações de rebeliões em que se fizeram reféns nos últimos cinco anos. No entanto, é indispensável salientar que o trabalho do Conselho da Comunidade é de fiscalização da aplicação da Lei de Execuções Penais. Portanto, a atuação do Conselho visa muito mais zelar pela integridade física e moral do preso, melhorar as condições carcerárias e de trabalho dos agentes penitenciários e assegurar o cumprimento da LEP como um elemento fundamental da ordem pública, do que eventualmente mediar em incidentes prisionais.

49. O agente penitenciário Marcus Vinícius Tavares Gavião, o Playboy, foi acusado pelo Ministério Público do Estado do Rio de Janeiro de entregar aos presos armas e chaves para que pudessem circular pelo presídio. Ele teria recebido R\$ 400 mil pelo serviço, de acordo com a denúncia. Playboy e 24 presos foram denunciados por homicídio duplamente qualificado (motivo torpe e impossibilidade de defesa da vítima). Cf. "Promotoria denuncia 25 suspeitos de matar rivais em motim em Bangu", Folha de S.Paulo, caderno Cotidiano, 5/10/2002, p.C3.

50. Cf. "Secretaria de Justiça confirma assinatura", $O$ Globo, 2. ed., caderno Rio, 13/09/2003, p.13. A equipe de negociação assinou o documento com as reivindicações dos presos, "apenas para caracterizar que o governo tomara ciência das reivindicações". O Globo, 2. ed., caderno Rio, 13/09/2003, p.13.

51. "Uma cidade só de reféns", O Dia, 2. ed., caderno Polícia,13/09/ 2003, p.1; "Lojas e escolas continuam fechadas por ordem do tráfico em nove bairros: Presença da PM não supera temor de comerciantes e diretores de escolas", O Globo, caderno Rio, 13/09/2002, p.15.

52. "Lojas e escolas continuam fechadas por ordem do tráfico em nove bairros: Presença da PM não supera temor de comerciantes e diretores de escolas", O Globo, caderno Rio, 13/09/2002, p. 15. Ler ainda: "Três dias sem comércio e aulas em Ramos: Lojas e escolas permanecem fechadas em sinal de luto por ordem dos traficantes do morro do Adeus", O Globo, 2. ed., caderno Rio, 14/09/2002, p.21.

53. Governos do Acre, de Brasília e de Pernambuco recusaram a transferência de bandido. Cf. "Benedita pede prisão federal para BeiraMar: FH diz que traficante veio para o Rio por ordem da justiça e só pode sair com nova determinação judicial", $O$ Globo, 2. ed., caderno Rio, 14/09/2003, p.16. Fernandinho Beira-Mar foi transferido de Bangu 1 para o Batalhão de Choque da Polícia Militar, no centro do Rio.

54. "O governo do estado ficou de quatro para um traficante. Este é o episódio mais grave dos últimos anos", afirmou o candidato a governador da Frente Trabalhista, Jorge Roberto Silveira. Usando o tempo da candidata Solange Amaral, o prefeito Cesar Maia afirmou que o "Estado está sem governo e sem política de segurança pública". $C f$. "Benedita é alvo nos programas de TV: Jorge pede renúncia da governadora e Solange mostra imagens de Bangu 1", O Globo, 3. ed., caderno O País, 14/09/2002, p.12. Ler ainda: "Tucanos culpam PT pela rebelião: Serra diz que parte da responsabilidade é da governadora do Rio", O Globo, caderno Rio, 2. ed., 13/09/2002, p.16. "Lula diz que Benedita é vítima de sabotagens: Candidato à Presidência compara atual crise com arrastões em Copacabana que prejudicaram a petista em 92", O Globo, 3. ed., caderno O País, 14/09/2002, p.12. 
55. "Secretaria de Segurança assumirá Bangu 1: De acordo com secretário, dentro de uma semana, policiais substituirão agentes penitenciários no presídio", O Globo, 2. ed., caderno Rio, 13/09/2002, p.14.

56. Depoimento público de Paulo Saboya sobre sua gestão à frente da Secretaria de Justiça no governo Benedita, na Universidade Candido Mendes-Ipanema, no dia 13 de outubro de 2003.

57. "Major assume Desipe", Jornal do Brasil, 2. ed., caderno Cidade, 15/09/2002, p.C3. O major Hugo Freire era o coordenador do núcleo de inteligência do sistema penitenciário. Em entrevista, nesta matéria, afirmava que a qualquer momento podiam estourar rebeliões lideradas pelo PCC de São Paulo em pelo menos 10 Estados do país. "No momento, o núcleo está monitorando, há cerca de 15 dias, a possibilidade de uma megarrebelião anunciada pelo PCC. No Rio, o contato é com o Comando Vermelho", disse.

58. Cf. "São Paulo exporta normas anti-facções", Jornal da Tarde, caderno Cidade. Disponível em:

$<$ http://www.jt.estadao.com.br/editorias/2002/09/18/ger026.html $>$. Acesso em: 30 set. 2003.

Ainda sobre a notícia de que a resolução do RDES era da Secretaria de Justiça, ler: "Após rebelião, 'Beira-Mar' vai ficar isolado", O Estado de S.Paulo, caderno Cidades, 13/09/2002. Disponível em:

$<$ http://www5.estado.com.br/editorias/2002/09/13/cid029.html $>$. Acesso em: 30 set. 2003 .

59. "Vamos explicar para o preso que ele não manda mais na cadeia. Vamos acabar com as mordomias", disse o novo diretor do Desipe, major PM Hugo Freire Vasconcellos Filho. Cf. "Desipe declara guerra às facções nos presídios: Novo diretor do Departamento do Sistema Penitenciário adota linha-dura: "Vamos acabar com as mordomias", O Globo, 3. ed., caderno Rio, 16/09/2002, p.14. Ler ainda: "Governo anuncia retaliações contra presos: Detentos perderão privilégios, como visita; serviço de inteligência irá investigar rendimento de agentes penitenciários", Folha de S. Paulo, caderno Cotidiano, 13/09/2002, p.C3.

60. O primeiro Estado a importar uma resolução paulista foi o Rio. "São Paulo exporta normas anti-facções”, Jornal da Tarde, 18/09/2002, caderno Cidade. Disponível em:

$<$ http://www.jt.estadao.com.br/editorias/2002/09/18/ger026.html>.

61. A resolução SEJGAB n ${ }^{\circ} 13$ de 12/09/2002 foi publicada no Diário Oficial $n^{\circ} 175$, Parte I, do Estado do Rio de Janeiro do dia 16/09/2002, p. 16 .

Segundo o art. $3^{\circ}$ da resolução, o preso que for enquadrado no RDES deverá ser submetido às seguintes regras para que tenha seus direitos garantidos:

- conhecimento dos motivos de inclusão no RDES;

- saída da cela para banho de sol, no mínimo uma hora por dia;

- acompanhamento técnico programado;

- duração de duas horas semanais para as visitas de esposa, companheira, ascendente, descendente e colaterais, conforme regulamentação própria, da espécie;

- remissão do RDES, à razão de um dia descontado por seis dias normais, sem falta disciplinar, com possibilidade de serem remidos, no máximo 25 dias e cumpridos 155 dias de regime;

- a ocorrência de falta disciplinar determina a perda de tempo anteriormente remido;

- contato com o mundo exterior pela correspondência escrita e leitura; - entrega de alimentos, peças de roupas e de abrigo, e objetos de higiene pessoal, uma vez ao mês, pelos familiares constantes no rol de visitas;

- o cumprimento do RDES exaure a sanção e nunca poderá ser invocado para fundamentar nova inclusão ou desprestigiar o mérito do sancionado, salvo, neste último caso, a má conduta denotada no curso do regime e sua persistência no sistema comum;
- a inclusão e a exclusão do preso no RDES serão comunicadas em 48 horas ao Juízo da Execução Penal;

- proibição de visita íntima;

- suspensão de regalias concedidas anteriormente ao ingresso no estabelecimento de cumprimento do RDES.

62. A remuneração média de um agente, que precisava ter apenas o nível médio de escolaridade, era de $\mathrm{R} \$ 1.500,00$. Cf. “'É preciso o mínimo de contato': Secretário admite ser 'praticamente impossível impedir a corrupção", O Estado de S.Paulo, caderno Cidades, 4/11/ 2002. Disponível em:

$<$ http://www.estado.estadao.com.br/editorias/2002/11/04/ cid016.html>. Acesso em: 30 set. 2003.

63. As informações seriam enviadas ao serviço de inteligência da secretaria para monitoramento, por exemplo, de casos de enriquecimento ilícito. Cf. "Governo do Rio anuncia retaliações contra presos" Folha on line, 13/09/2002. Disponível em:

<http://www1.folha.uol.com.br/folha/cotidiano/ult95u58961.shtml>. Acesso em: 30 set. 2003.

64. "Rio refém do medo: Ação de grupos e onda de boatos põem cidade em clima de estado de sítio; Benedita vê razão política", $O$ Globo, caderno Rio, 1/10/2002, p.1; "Tráfico transforma o Rio na capital do medo: Polícia Federal investiga quem ordenou o fechamento do comércio e das escolas", Jornal do Brasil, 2. ed., caderno Cidade, 1/10/ 2002, p.1; "Ameaça do tráfico e boatos aterrorizam o Rio", Folha de S.Paulo, caderno Cotidiano, 1/10/2002; "Rio vive dia de ameaça e medo: Em nome do crime, comércio e escolas fechados", O Estado de S.Paulo, caderno Cidades, 1/10/2002, p.C1.

65. "Ações de traficantes ou manobra política? Lojas e escolas fecharam em áreas dominadas pelo $\mathrm{CV}$; o mesmo não aconteceu em redutos de facções rivais", $O$ Globo, 3. ed., caderno Rio, 1/10/2002, p.19.

66. "Polícia sabia que tráfico ia paralisar o Rio", O Dia, 2/10/2002, p.1. Ler ainda a transcrição da conversa entre o traficante Marquinho Niterói, do CV, com um cúmplice: "Vamos dar um blecaute na Zona Sul". O Dia, 2/10/2002, p.1.

67. "Boatos foram planejados: Gravações do MP, entregues ao governo dia 17 , mostram traficantes querendo paralisar o Rio", Jornal do Brasil, caderno Rio, 2/10/2002, p.C1.

68. "Governadora: comércio abre hoje", O Globo, 2. ed., caderno Rio, 1/10/2002, p.20.

69. "Roberto Aguiar quer acabar com separação de facções em presídios: Secretário de Segurança proibiu advogados de visitar presos no BPChoque", O Globo, 2. ed., caderno Rio, 1/10/2002, p.23.

70. No primeiro turno, dez estados receberam tropas federais. O envio de tropas é comum nas eleições. Em 1994, 12 estados, inclusive o Rio de Janeiro, receberam as Forças Armadas. Em 1996, o Exército visitou dez unidades da Federação. Dois anos depois, nove estados pediram e foram atendidos pelo TSE, que determinou o envio das forças federais. Cf. "Militares vão às ruas", Correio Braziliense, 27/10/2002. Disponível em:

$<$ http://www2.correioweb.com.br/cw/EDICAO_20021027/ pri_tem_271002_341.htm>. Acesso em: 30 set. 2003.

71. "Bandidos tentam invadir Bangu 3", O Globo, caderno Rio, 16/ 10/2002, p.1

72. Os jornais fizeram listas dos mais importantes bandidos que seriam resgatados de Bangu 3, entre eles: Isaías do Borel, o Rolinha, o Magno da Mangueira, o Polegar, o Aldair da Mangueira

73. "O objetivo era desmoralizar o governo, do qual eles, por motivos óbvios, não gostam, porque nunca sofreram tanta repressão. Eles estão descapitalizados e tiveram queda na venda de entorpecentes. A polícia já estava em estado de alerta", disse Jacqueline Muniz, coordenadora de Segurança Pública. "Rocinha, o QG do terror", O Globo, caderno Rio, 17/10/2002, p.14. 
74. Luiz Eduardo Soares foi candidato a vice-governador na chapa da governadora Benedita. Foi também coordenador do programa de segurança do Partido dos Trabalhadores (PT) na campanha de Lula.

75. "Benedita pede Exército: Forças Armadas vão garantir segurança no segundo turno das eleições", Jornal do Brasil, 2. ed., caderno Rio, 17/10/2002, p.C3.

76. O aparato contou com 47.350 pessoas, somados os efetivos das polícias Civil, Militar e Federal e das Forças Armadas. Entre 13 e 15 blindados dos tipos Cascavel, armados com canhões, e Urutu, para o transporte de tropas, além de jipes, foram destacados para o patrulhamento ostensivo e deslocamento de pessoal entre os 30 "pontos fortes", distribuídos por áreas de risco da capital, Nilópolis, Belford Roxo, São João de Meriti, Nova Iguaçu e Duque de Caxias. "Eleição no Rio terá blindados do Exército", O Estado de S.Paulo, editoria Nacional, 25/10/2002. Disponível em:

$<$ http://www.estado.estadao.com.br/editorias/2002/10/25/ pol008.html>. Acesso em: 30/set. 2003.

77. Trata-se da resolução SSP n ${ }^{\circ} 572$ de 25/10/2003, assinada pelo secretário de Estado de Segurança Pública, Roberto de Aguiar.

78. "Bloqueador de celular em Bangu 1 já está instalado", Diário Oficial do Estado do Rio de Janeiro, no 194, Parte I, 11/10/2002, p.1.

79. Resolução SSP n 572 art. $2^{\circ}$, II.

80. "Regras mais duras para Bangu 1: Polícia suspende encontros íntimos, limita visitas e obriga presos a usar uniforme", O Globo, caderno Rio, 31/10/2002, p.17. Segundo a resolução SSP n ${ }^{\circ} 572$, art. 17, "não será concedida a visita íntima em razão da Segurança da Unidade".

81. "Uma secretaria só para presos: Governadora eleita anuncia pasta especial para cuidar do sistema penitenciário", O Globo, caderno Rio, 26/12/2002, p.12.

82. O secretário Astério Pereira dos Santos apresentou seus objetivos administrativos em palestra gravada na UCAM-Ipanema no dia 5/5/ 2003. "Os principais objetivos da política penitenciária são: 1. Não restringir a ação do Estado a providências contra fugas e motins mas sim, respeito à integridade física e moral conforme mandamento constitucional; 2. Elaborar projetos de reforma das legislações federal e estadual de forma a compatibilizar os princípios legais à realidade penitenciária; 3. Integrar o sistema penitenciário na política governamental de defesa da sociedade; 4. Tornar efetivo o cumprimento das penas restritivas de direito; 5. Não permitir o recolhimento de presos provisórios e condenados nas delegacias policiais; 6 . Implantar o exame de classificação para os condenados tornando-os premissa fundamental para o tratamento penitenciário a ser aplicado; 7. Agilizar os processos de saída de presos recolhidos aos estabelecimentos prisionais, tornando mais céleres as tramitações dos livramentos condicionais, indultos, das progressões de regime e da remição; 8. Não deferir privilégio ou fazer discriminação ao condenado no curso do cumprimento da pena; 9. Obedecer nos projetos de edificações penitenciárias aos modernos princípios da arquitetura prisional com vistas, principalmente, à racionalização dos custos, à localização adequada e à segurança compatível."

83. Ler: "Briga de Garotinho e Cesar pode cancelar convênio: Prefeito diz que, se governadora não desmentir marido, acabará com acordo que prevê repasse de R $\$ 100$ milhões", $O$ Globo, caderno Rio, p.17; "A conta que a cidade vai pagar: Rompimento de convênio entre estado e prefeitura pode causar impacto na segurança e também na economia", O Globo, caderno Rio, 29/09/2003, p.10. Por outro lado, o governo federal não liberou até o final do mês de setembro cerca de R\$ 40 milhões para o Estado do Rio. Cf. 'Ministro da Justiça admite liberar verba para o estado: Governadora volta a Brasília para negociar com a União", O Globo, caderno Rio, 29/09/2003, p.11.

84. Diário Oficial n ${ }^{\circ} 49$, de 14/03/2003. Punições semelhantes já são impostas aos detentos que cumprem pena nos presídios paulistas de Presidente Pudente e outro em Taubaté. A diferença é que no Rio ha- verá "apenas uma galeria para punir os presos que tenham cometido uma falta grave", segundo o secretário Astério. Cf. "Regras mais rigorosas para detentos: Com novo regime disciplinar, presos podem ficar sem visitas íntimas", $O$ Globo, caderno Rio, 15/03/2003, p.13. O secretário lastimou que dispusesse de uma única galeria, em entrevista ao Jornal do Brasil. "O ideal é que eu tivesse uma unidade exclusiva para esses regimes. Por exemplo: todo o presídio de Bangu 1 com suas quatro galerias e suas 48 celas. Como não era possível, peguei uma galeria com 12 celas para isso. Com o fim do castigo, ele vai para outra galeria dentro da unidade. O regime disciplinar será mantido. Isso acalma os presos que não fazem nada por terem medo de ir para o regime". Cf. "Durmo com a cabeça tranqüila", Jornal do Brasil, entrevista, 17/08/2003, p.A10.

85. Esta Resolução teve seu prazo de vigência prorrogado por mais 60 dias pela Resolução SEAP/GAB n 28 de 30 de julho de 2003. Publicada no Diário Oficial n ${ }^{\circ} 146$ de 06/08/2003.

86. Publicada no Diário Oficial n ${ }^{\circ} 126$, de 09/07/2003. Esta matéria também foi alvo de regulação pelo secretário de Justiça, Paulo Saboya, em termos assemelhados.

87. Informação dada pelo secretário em palestra gravada na UCAMIpanema no dia 5/5/2003. O problema da superlotação carcerária está presente em todo o Brasil. Só de janeiro a julho de 2003, entraram no sistema quase 50 mil novos presos. No mesmo período foram criadas menos de 20 mil vagas. Em 2002, o país tinha 240 mil presos; em agosto de 2003, quase 290 mil. Até dezembro de 2003, estima-se que existirão mais de 300 mil presos, o que corresponderá - se nada for feito - a quase o dobro da capacidade do sistema carcerário existente em agosto de 2003. "Por isso os secretários de Justiça de todo o país encaminharam ao Presidente Luiz Inácio Lula da Silva a 'Carta do Rio' em que declararam estado de emergência no sistema penitenciário brasileiro." Cf. "Secretários declaram emergência no sistema penal: Em carta a Lula, pedem abertura de cem mil vagas em presídios para evitar falência do sistema”, O Globo, caderno O País, 21/ 08/2003, p.11.

88. A mobilização criminosa alastrou-se por 33 bairros de quatro municípios e da capital. Nove pessoas ficaram feridas - sete delas queimadas em ataques a ônibus com coquetéis molotov. Bombas explodiram em Botafogo, Tijuca e Ipanema. Trinta e oito ônibus foram destruídos: 25 incendiados e 13 depredados.

89. "Explosão na Vieira Souto: Bombas atingem prédios em Ipanema. Parte do comércio fecha", O Dia online, caderno Polícia, 25/02/2003. Disponível em:

$<$ http://odia.ig.com.br/odia/policia/pl250216.htm>. Acesso em: 30/set. 2003. Acesso em: 30/set. 2003.

90. "Vamos agir com todo o rigor previsto na lei. Antes, os baderneiros eram detidos, indiciados por danos e liberados após pagamento de fiança. Agora, todos serão autuados com base no Artigo 14 da Lei n ${ }^{\circ} 6368$ / 76. Ninguém vai sair da delegacia rindo da polícia”, afirmou o delegado Álvaro Lins. Cf. "Crime sem fiança: Polícia detém 45 suspeitos da baderna, indiciados por associação ao tráfico", O Dia online, caderno Polícia, 25/02/2003. Disponível em:

$<$ http://odia.ig.com.br/odia/policia/pl250217.htm>. Acesso em: 30/set. 2003.

91. Quinze favelas foram vasculhadas e cinco ocupadas por tempo indeterminado. Setenta e oito pessoas foram presas, e 11 armas e mais de 100 quilos de drogas apreendidos.

92. "Uma semana que será difícil de esquecer: Bombas, mortes e ônibus queimados marcaram a semana de aniversário do Rio", Jornal do Brasil, 2. ed., caderno Rio, 2/03/2003, p.C1.

93. "Ordem partiu de Bangu 1: Governo reconhece que preso comandou ataques. Marcinho VP, homem de confiança de Beira-Mar, é o maior suspeito". O Dia, caderno Geral, 10/04/2003, p. 8. Os comparsas de Beira-Mar que teriam promovido as mobilizações seriam, de acordo com a Polícia, Marcinho VP, Isaías do Borel, Lambari e Marquinho Niterói. 
94. "Exército ocupa as ruas da cidade: Presença da tropa tranqüiliza carioca", Jornal do Brasil, 2. ed., caderno Rio, 2/03/2003, p.C1. Ler ainda: "Rio monta operação inédita para proteger Sambódromo: Polícia vai escoltar carros alegóricos e infiltrar agentes até na avenida”, $O$ Globo,caderno Rio, 2/03/2003, p.1.

95. "Turismo não se rende ao tráfico e Rio terá o melhor carnaval em 10 anos: Faturamento do setor deverá crescer $40 \%$ em relação ao ano passado", O Globo, caderno Rio, 2/03/2003, p.15. Ler ainda: "Pesquisa: $70 \%$ dos turistas pretendem voltar: mesmo ouvidos durante uma semana violenta no carnaval, visitantes querem estar no Rio nesta época em 2004", O Globo, caderno Rio, 8/03/2003, p.17.

96. "Um carnaval mais violento: homicídios e assaltos aumentam, mesmo com Forças Armadas nas ruas", O Globo, caderno Rio, 5/03/2003, p.9.

97. "Motorista rompe bloqueio e é morto a tiros: Militares disparam contra carro com casal que não obedeceu à ordem de parar", O Globo, caderno Rio, 5/03/2003, p.9.

98. "Exército mata professor em blitz no Rio: Governadora pede que militares fiquem mais 30 dias nas ruas", Jornal do Brasil, 5/03/2003, p.1. Observação: Foi neste momento que o secretário Astério reeditou o RDES, pela Resolução SEAP/GAB n 8, de 7 de março de 2003.

99. "Exército já treina para combater tráfico no Rio: Objetivo é preparar militares para atuar com poder de polícia nas ruas", O Globo, 28/09/2003, p.1; Ler ainda: "Manual contra a guerra urbana: Exército elabora normas para treinar militares no combate ao crime organizado", O Globo, caderno Rio, 28/09/2003, p.18; "Exército como último recurso: Entidades discutirão estratégia para evitar emprego das Forças Armadas contra o crime", O Globo, caderno Rio, 29/09/2003, p. 10 .

100. Cf. "Juízes pedem novas leis para combate à violência: OAB acusa Beira-Mar pela execução de magistrado em São Paulo”, O Globo, 16/ 03/2003, p.1. Ler ainda: "Investigação leva a Beira-Mar: Traficante do Rio teria sido interrogado ontem, junto com outros criminosos do presídio", O Globo, 2. ed., 16/03/2003, p.15; "Executado juiz que cuidava de 'Beira-Mar', Jornal do Brasil, 17/03/2003, p.1.

101. “Ao confronto", $O$ Globo, 16/03/2003, p.1.

102. "Alckmin quer mais rigor para preso: O governador vai propor endurecimento na Lei das Execuções Penais", Folha de S.Paulo, caderno Cotidiano, 17/03/2003, p.C1.

103. "Rio quer garantir integridade dos magistrados: Cogita-se o uso do sistema Juiz Sem Rosto, em que o criminoso desconhece nome de quem lhe aplicou a pena", $O$ Globo, caderno Rio, 17/03/2003, p.9.

104. "Câmara aprova mais rigor no sistema carcerário: Entre mudanças na Lei de Execuções Penais está isolamento por período de até um sexto da pena", O Estado de S.Paulo, caderno Cidades, 2/04/2003. Disponível em:

$<$ http://www.estado.estadao.com.br/editorias/2003/04/02/ cid040.html>. Acesso em: 30/set. 2003.

105. "Pena mais dura para morte de servidor: comissão do Senado aprova projeto que aumenta punição em até dois terços", $O$ Globo, caderno O País, 20/03/2003, p.10. O Senado aprovou em abril um projeto de lei que amplia de 30 para 40 anos o prazo máximo de cumprimento de penas de prisão e classifica de homicídio qualificado os crimes contra magistrados, integrantes do Ministério Público, jurados e policiais. Cf. "Senado aprova projeto que aumenta penas de prisão", Agência Estado, 16/04/2003. Disponível em:

$<$ http://www.estadao.com.br/agestado/noticias/2003/abr/16/225.htm>. Acesso em: 30/set. 2003.

106. O Quadro 1 foi publicado em: Agencia Senado, 02/07/2003. Disponível em:

<http://www.senado.gov.br/agencia/noticias/2003/7/not028.asp>. Acesso em: 30/set. 2003.
107. "Polícia só vai patrulhar em comboio", JB online, 10/04/2003. Disponível em:

$<$ http://jbonline.terra.com.br/destaques/guerra_trafico/ mat_1004_policia.html>. Acesso em: 30/set. 2003.

108. Na semana anterior, cinco bairros tinham sido atingidos por tiros e bombas. Cf. "Medo em onze bairros: Comerciantes decidem fechar lojas mais cedo após receber cartas assinadas com nome de facção criminosa", O Dia online, 8/04/2003. Disponível em:

$<$ http://odia.ig.com.br/odia/policia/pl080401.htm>. Acesso em: 30/set. 2003.

109. "Na carta - escrita a mão por uma mulher que atua como pombocorreio de Isaías -, o bandido chegou a dizer que o CV já teria o apoio das Farc - Forças Revolucionárias da Colômbia e da facção paulista Primeiro Comando da Capital - PCC. O Dia teve acesso à carta endereçada a Dinho Porquinho, que controlava o tráfico de drogas na Favela de Antares, em Santa Cruz". Cf. "Mensagens atribuídas a traficantes", O Dia online, caderno Polícia, 8/04/2003. Disponível em: $<$ http://odia.ig.com.br/odia/policia/p1080402.htm>. Acesso em: 30/set. 2003.

110. Tratava de questões como ressocialização de presos e reforma do sistema penitenciário e até do Código Penal. "Assinado" por presos de 11 presídios, o documento empregava muitos termos específicos da linguagem jurídica.

111. Os grevistas reivindicavam o pagamento imediato do 13 ' salário e a elevação do piso de $R \$ 151$ para $R$ \$ 240. "Mais um desafio para a segurança do Estado: Agentes penitenciários entraram em greve", O Dia online, caderno Polícia, 9/04/2003. Disponível em:

$<$ http://odia.ig.com.br/odia/policia/p1090407.htm>. Acesso em: 30/set. 2003.

112. Para um resumo deste caso, ler: "Mais uma vez de volta à cadeia: Bandido que fugiu do Batalhão de Choque comandava seqüestro de empresário paulista", O Globo, 2. ed., caderno Rio, 8/08/2003, p.14. 113. O secretário Astério confirmou que houve feridos, encaminhados ao IML - Instituto Médico Legal para a realização de exames. "Vai tudo ser apurado, mas, enquanto eles estão levando tiros de borracha, meus diretores estão levando tiros de chumbo e morrendo", disse ele, em referência aos assassinatos do diretor de Bangu 3, Abel Silvério de Aguiar, há duas semanas, e do chefe de segurança do complexo de Bangu, Paulo Roberto Rocha, em julho. Cf. "Presos ligados ao CV fazem greve de fome; governo corta visitas", Folha de S.Paulo, 19/ 08/2003. Disponível em:

$<$ http://noticias.bol.com.br/destaques/2003/08/19/ult95u80570.jhtm>.

114. O Conselho da Comunidade da Comarca do Rio de Janeiro Comerj foi criado e instalado na forma dos artigos 80 e 81 da Lei $n^{\circ}$ 7210 de 11 de julho de 1984. É um dos órgãos que fiscaliza a execução penal.

115. Para uma análise detalhada deste episódio, ler: Caldeira (2003).

116. Manifesto de sete páginas do CV lido e entregue ao Conselho da Comunidade para ser repassado às autoridades, à imprensa e à sociedade.

117. A resolução $\mathrm{SEAP} / \mathrm{GAB} \mathrm{n}^{\circ} 8$, de 07 de março de 2003, indica no seu artigo $7^{\circ}$ : "Será realizada, em caráter provisório, a galeria 'A' da Unidade Prisional Laércio Pellegrino, para cumprimento das sanções previstas na presente Resolução".

118. Existe uma mobilização contrária à política do cárcere duro: o movimento antiterror. Esta corrente de opinião é composta por advogados criminalistas, professores de Direito Penal e de Direito Processual Penal, defensores públicos, membros do Ministério Público, magistrados e cidadãos. Ver o Manifesto Antiterror e a Carta de Princípios do Movimento, que era apoiado por 16 entidades e cerca de 300 operadores do Direito em junho de 2003, no site do IBCCRIM (Instituto Brasileiro de Ciências Criminais): www.ibccrim.org.br . A Carta de Princípios foi lançada na Faculdade de Direito da Universidade de 
São Paulo, no dia 20 de maio de 2003. Ler também: Boletim do IBCCRIM de fevereiro, maio e junho, que contém vários artigos contrários ao RDD - Regime Disciplinar Diferenciado.

119. Durante visita à Vara de Execuções Penais, no dia 17 de setembro de 2003, a juíza Ana Paula Barros comentou que não existiam, por exemplo, mandados de segurança impetrados contra a aplicação da regulamentação disciplinar do RDES, e demais resoluções impostas desde o governo Benedita. Ou seja, os presos ligados ao Comando Vermelho não optaram pela via judicial para contestar a nova regulamentação.

120. "Juiz autoriza a volta de Beira-Mar para o Rio: Secretário de Administração Penitenciária do Estado diz que vai recorrer porque não aceita a transferência do preso", O Globo, caderno Rio, 2/09/2003, p.21. Ler ainda: "Rosinha recorrerá ao STJ contra a medida: Ministro Márcio Thomaz Bastos diz que decisão de juiz paulista foi um equívoco", O Globo, caderno Rio, 3/09/2003, p.12. "Alckmin: Beira-Mar não volta para o Rio: governador e ministro discutem cooperação entre polícias nos estados", O Globo, caderno Rio, 27/09/2003, p. 15.

121. Todo dia, a mídia expõe as mazelas do sistema penitenciário do Rio de Janeiro. Ler, por exemplo: "Bloqueadores de celular já não funcionam em Bangu: Estado diz que Bangu 1 deixou de ser prisão de segurança máxima", O Globo, 7/09/2003, p.1.

122. O governo Benedita da Silva, por exemplo, endureceu a regulação disciplinar dos cárceres, além de ter realizado inúmeras apreensões de armas, explosivos e celulares nos presídios. No entanto, nenhum funcionário do Desipe foi demitido. Apenas $6,2 \%$ das 225 sindicâncias contra funcionários, desde a posse da governadora petista, em 6 de abril, resultaram em punições. No período de abril a novembro de 2002, só os acusados em 14 investigações administrativas foram punidos. A legislação propiciava a lentidão nas investigações internas. Antes de perder o emprego, o funcionário passava por sindicância (das 225, 187 permanecem como sindicâncias), investigação preliminar e, depois, inquérito administrativo (eram 24 no Desipe em novembro de 2002). "É preciso o mínimo de contato: Secretário admite ser 'praticamente impossível' impedir a corrupção", O Estado de S.Paulo, caderno Cidades, 4/11/2002. Disponível em:

$<$ http://www.estado.estadao.com.br/editorias/2002/11/04/ cid016.html>. Acesso em: 30/set. 2003.

123. Bilhetes encontrados pela polícia e por promotores evidenciaram que líderes da organização - PCC, mesmo isolados no Regime Disciplinar Diferenciado, continuavam recebendo informações e dando ordens, inclusive para matar, de dentro do Centro de Readaptação Penitenciária de Presidente Bernardes. No parlatório, não havia contato físico. Preso e advogado eram separados por um vidro. Não havia, porém, isolamento de som. O líder do PCC, Marcola, lia as mensagens trazidas pelo seu advogado. Depois transmitia suas decisões, que eram anotadas pelo advogado, aos outros membros da rede criminosa. Cf. "Polícia desvenda plano terrorista do PCC: Bilhetes revelam até intenção de atacar estação de metrô; para Ministério Público, ala radical continua na ativa", Folha de S.Paulo, caderno Cotidiano, 2/10/2003, p.C4. Ler ainda: "Alerj torna obrigatória revista em advogados: Objetivo da lei, que ainda precisa de sanção de Rosinha, é dificultar entrada de armas, drogas e celulares em presídios", O Globo, caderno Rio, 2/10/2003, p.22.

124. Sobre a rebelião de novembro de 2001, ler: "Entrada de armas pesadas em Bangu 3 não é explicada; Agentes são suspeitos de depredar a escola dos presos", $O$ Globo, 2. ed., caderno Rio, 24/11/2001, p.23; "Vinte horas de tensão e medo em Bangu 3", $O$ Globo, 3. ed., caderno Rio, 24/11/2001, p.14. Sobre a rebelião de outubro de 2002, ler: "Bandidos tentam invadir Bangu 3", O Globo, caderno Rio, 16/ 10/2002, p.1.

125. Aliás, nas conversas com presos, escutam-se frases que improvisam sobre esse mesmo tema. Na primeira visita que fiz a Bangu 3, o faxina já dizia o seguinte: "Se bacana pode roubar, pobre também pode". Num Estado em que o secretário de Esportes, Chiquinho da Manguei- ra, supostamente comparecia a Bangu 3, onde estavam os traficantes que controlavam aquele morro, não dá para entender por que um bandido se sente discriminado quando está encarcerado. Ler: "Escuta telefônica comprometeria Chiquinho: deputado diz que homem citado por traficante em gravação autorizada pela Justiça seria o secretário de Esportes", O Globo, caderno Rio, 14/08/2003, p.18; "Chiquinho: três inquéritos no MP: Comissão da Alerj ouvirá amanhã o secretário pela segunda vez", $O$ Globo, caderno Rio, 24/08/2003, p.25; "Caso Chiquinho acaba em pizza: Alerj arquiva pedido de cassação de mandato de deputado que teria pedido trégua para tráfico", O Globo, caderno Rio, 10/09/2003, p.11. Sobre o caso do Propinoduto, ler: "Propinoduto causou rombo de R\$200 milhões à União: Justiça liberta representantes de banco suíço envolvido no escândalo", O Globo, 28/08/2003, p.1.

126. Sobre a "cultura do controle", ler: Garland (2001: 6-20). Para uma breve caracterização da "cultura do controle", ler: Caldeira (2003: 111112).

127. No dia 10 de setembro de 2003, o secretário de Segurança, Anthony Garotinho, anunciou que quatro mil policiais civis e militares estariam nas ruas do Estado a partir das 22 horas. Segundo informações obtidas pela Secretaria de Segurança, através do disque-denúncia e de investigações, atos violentos poderiam atingir vias expressas, prédios públicos, consulados, shoppings e hotéis. O Comando Vermelho supostamente promoveria atos de vandalismo para "comemorar" e não deixar "passar em branco" o primeiro aniversário da chacina de seus adversários em 11 de setembro de 2002 em Bangu 1. Cf. "Alerta máximo contra o crime: Polícia põe 4 mil homens nas ruas após saber que bandidos planejam atos de vandalismo para marcar o aniversário da rebelião em Bangu 1", O Dia online, 11/09/2003. Disponível em: $<$ http://odia.ig.com.br/odia/policia/pl1 10901.htm>. Acesso em: 30/set. 2003.

\section{REFERÊNCIAS BIBLIOGRÁFICAS}

CALDEIRA, C. Bangu 3: Desordem e ordem no quartel-general do Comando Vermelho. Revista Inteligência, n.22, p.91-115, jul./set. 2003. Disponível em:

$<$ http://insightnet.com.br>. Acesso em: 15/10/2003.

FOUCAULT, M. Estratégia, poder-saber. Organização e seleção de textos Manoel Barros da Motta. Tradução de Vera Lúcia Avellar Ribeiro. Rio de Janeiro: Forense Universitária, 2003a.

. Vigiar e Punir: o nascimento da prisão. Tradução de Raquel Ramalhete. 27. ed. Petrópolis: Vozes, 2003b.

GARLAND, D. The culture of control: crime and social order in contemporary society. Chicago: The University of Chicago Press, 2001.

ILANUD. Incidentes prisionais no sistema carcerário. São Paulo: Ilanud, n.9, 1998.

SOARES, L.E. A politização da insegurança. O Globo, Rio de Janeiro, 17 out. 2002, Caderno Rio, p.15.

SOUZA, P. de. Narcoditadura: o caso Tim Lopes, crime organizado e jornalismo investigativo no Brasil. São Paulo: Labortexto Editorial, 2002.

Cesar Caldeira: Professor da Escola de Ciências Jurídicas da Universidade Federal do Estado do Rio de Janeiro, Professor da Faculdade de Direito da Universidade Candido Mendes-Ipanema. Atual membro do Conselho Penitenciário do Estado do Rio de Janeiro, responsável por inspeções nas unidades prisionais. 